\title{
Sciendo
}

Research Article

(C) 2019 Tran Thi Xuan Anh and Le Quoc Tuan This is an open access article licensed under the Creative Commons Attribution-NonCommercial-NoDerivs License (http://creativecommons.org/licenses/by-nc-nd/3.0/).

\section{The Relationship between Ownership Structure and Dividend Policy: An Application in Vietnam Stock Exchange}

\author{
Dr. Tran Thi Xuan Anh \\ Finance Faculty, \\ Banking Academy, \\ Hanoi, Vietnam
}

\section{MSc. Le Quoc Tuan}

Finance Faculty, Banking Academy, Hanoi, Vietnam

Doi: 10.2478/ajis-2019-0025

\begin{abstract}
This research examines the possible association between ownership structure and Vietnam listed companies' dividend payout policy over the period of $2009-2015$. We have investigated 642 listed firms in Hochiminh stock exchange and Hanoi stock exchange, using pannel data analysis. Ownership structure is described with two main sub-variables: ownership concentration and ownership composition. Specifically, the Herfindahl index (or H-index) was applied to measure the level of ownership concentration /dispersion for all major shareholders in the company, including the five biggest investors, corporate institutional investors, the ownership concentration level, and foreign investors. It has been observed that the $\mathrm{H}$-index of all major shareholders has an average of less than 0.5 but the value of the $H$-index of institutional investors at 0.594 indicates that institutional investors are more likely to be concentrated in the hands of large institutional investors. The result showed linear relationship between institutional ownership and the dividend rate, but not statistically significant for the relationship between managerial ownership and dividend payout ratio.
\end{abstract}

Keywords: Dividend Payout Policy, Ownership structure, Ownership concentration, $\mathrm{H}$-index

\section{Introduction}

A nature of a relationship between an ownership structure and the dividend policy proceeds from asymmetric information and agency problem existing potentially inside enterprises which have separations between ownership and management rights. Jensen and Meckling (1976) suggest that agency costs of equity could be reduced by paying higher dividends for its shareholders because it will result in lower "discretionary" cash flows available to be squandered away by managers. On the other hand with the payment of dividends managers are forced to access capital market to raise external capital to replenish fund paid out in dividends and it will reduce the opportunity for manages to use free cash flow for their perquisites activities as a results of asymmetric information (Abdullah, Ahmad and Rosland (2012, Easterbrook (1984), Rozeff (1982)). The dividend payout is considered as the primary control mechanism in which shareholders could limit ability of managers to abuse the free cash flow (Kuma, 2004). However, some empirical evidences suggest that share ownership is highly concentraded in developing countries such as Sri Lanka (Samarakoon, 1999). The managerial owners, individual owners, institutional owners, foreign owners and family owners 
are present in most companies. These different kinds of owners in a company setting may have different interests with their power and authority. The composition of ownership structure does not influence dividend policy uniformly over the countries and hence the impact of dividend policy to the ownership structure has been an interesting topic in the recent past across countries.

In Vietnam, researches about an effect of ownership structure on dividend policy are still limited both in size and research method. Hai Ly (2015) has shown that there were few researches about this matter in Vietnam, including Hai Ly (2011) \& Duong Kha (2012) with sample sizes just covering a part of listed companies in Vietnam. Additionally, those researches used the least square method for skewed data or period, so rejected pressure of obscurely specific factors inside businesses, there're one of reasons causing internal problems. On the other hand, results from developed countries tent to be more clear and stable than developing countries. Even researches in the same nation, there can bring different results. That recommends us for some remarkable problems. First, there need to select a suitable model in order to deal with internal problems on research. Second, the effect of ownership structure can depend on specific characteristics of national economy and culture (such as, a family ownership is very popular in Korean while a State ownership is so strong in China). Furthermore, a sample selection and timing study also can be effect on study result.

Specifically, in this study, the authors showed in 4 ratios which are less used in many previous studies about the effect of a centralization level of an enterprise's ownership structure and dividend policy, Herfindahl index ratios (or $\mathrm{H}$-index). We estimated Herfindahl index in every companies for all big shareholders (HINDEX_ALL), 5 major investors (HINDEX_LARGE), shareholders who are institutional investors (HINDEX_INSTI), and shareholders who are foreign investors (HINDEX_FOREIGN). Combining with the regression method for pannel data including the fixedeffect regression \& GMM, with sample including 642 listed companies on HOSE \& HNX. The result individually showed below with section 2 - analyzing study overview, section 3- presenting study method, and section 4, 5 - indicating the results of the effective level between ownership structure and dividend policy of Vietnamese companies.

\section{Literature Review}

\subsection{Theory perspective}

The signaling theory, free cash flow theory and agency theory are the main theoretical backbones of the dividend policy. The agency theory (Jensen, 1986; Jensen and Meckling, 1976) is the most principal theory used in a large number of studies involving ownership structures and affecting the dividend payout of firms. This theory stemmed from the conflicts in the relationships of the company, especially the principal-agent relationship between the shareholders (principal of the company) and executives (the agent). Managers take the duty of maximizing value for the owners. Nevertheless, in many cases, the executives can operate the company in the way that benefits themselves instead of the owners whom they represent for, especially if the manager is paid and their interest is unrelated to the company, resulting in agency costs.

The agency theory by referring to ownership concentration builds up two views on relationship between ownership concentration and the dividends. One perspective is that the conflict of interest arises between managers and the owners of the company can be alleviated through concentrated ownership (Harada \& Nguyen, 2011). This predicts the positive impact of concentration ownership on dividends (Abdullah, Ahmad, \& Roslan, 2012; Harada \& Nguyen, 2011). Another perspective of this relationship is that concentration owners prefer to have more private benefits from existing free cash flow and it would lead to lower the dividend payments (Harada \& Nguyen, 2011). This is predicted the negative relationship between concentration ownership and the payments of dividends.

Free cash flow theory argued that the agency cost can damage to the company in form of profit distribution. Free cash-flows from business operations and corporate profits, rather than redistribute to the owner in a legitimate manner through dividends or buy back shares, the administrator put into unnecessary or wasteful investment, causing damage to shareholders. 
Therefore, Easterbrook (1984) suggests that firms should pay dividend as it may be useful in reducing the free source of cash to be used on wasteful investment. However, the more concentration ownership structure, the more motivated shareholders to keep a close control on executive actions, is making a difficulty for managers to commit harmful behaviors to the public, what benefit him. Thus, the concentration level of the corporate ownership structure has a positive correlation with the dividend ratio of the firm. In addition, when managers have a vested interest in the company, they are motivated to maximize the value of the company. Therefore, the management's stock ownership can have the same impact on the dividend payout ratios of the business.

Signalling Theory (Ross, 1977) advocates that managers are the controllers in a company and stockholders are the owners of the firms and there is an information asymmetry between these two parties. Managers have more firsthand information about the firm than its shareholders do but they are not always willing to public for the shareholders (Miller \& Rock,1985). Hence the dividend policy could be considered as the signal for the firm's future projection proficiently (Miller and Rock (1985)) and Li and Zhao (2008) argued that dividend policy plays a leading role because it can be used to convey information to the shareholders. For example, the issuance of additional shares to raise capital may be seen by investors on the market as if the stock price of the company is higher than its real value or the decision to buy back shares in the market may be considered as a positive signal, the company is returning free cash flow to its owner, meaning less free cash flow for more expensive investment activities, etc.

However, the different types of ownership structure provide different information in the market from the financial decisions of the management. For instances, Joh and Ko (2007) pointed out that for household-owned enterprises, a decision to distribute profits by acquiring stocks was admitted by different ways in the market when the ownership structure varied. As for a centralized ownership structure, the stock acquisition to distribute cash flow is well received; for the purpose of the acquisition will not be for the benefit of large shareholders and block minority shareholders. Meanwhile, as for family-owned businesses with dispersed ownership structures, the stock acquisition is considered as a method to protect the interests of the family and assessed negatively by the market.

\subsection{Empirical evidences}

Studies on this topic focus on two main aspects: (1) how does the ownership concentration level affect the corporate dividend payout? (2) How does the existence of large shareholders influence dividend payout? The research divides the existing forms of large shareholders into the following main categories: State shareholders, family shareholders, institutional shareholders and foreign investors. The results focus on the following:

(1) How does the ownership concentration level affect the corporate dividend payout? It was argued that the more concentration the shareholder structure, the more likely it is that the business will tend to have less transparency, which results in a representative capital of the business will face an extreme conflict of interest, the large shareholders tend to gain more personal benefit through unclear legal transactions, so lower the dividend. Porta (2000) compared the dividend performance in 33 countries and found that the higher the concentration of shareholder structure, the lower the dividend ratio. Holderness and Sheehan (1988) studied the effect of shareholder concentration and dividend levels on firms of the same scale showing that the larger the shareholder dispersion level is, the higher dividend is paid, a company with a high concentration of shareholders.

Maury and Pajuste (2002) conducted research with companies in Finland and also showed the similar result indicating the negative relationship between the concentration of shareholder structure and dividend ratio, in particularly, the lower of dividend payout ratios when a leader is also as the large shareholder. Harada and Nguyen (2006) conducted a survey of the companies' dividend policy in Japan, Mancinelli and Ozkan (2006), in the Italian stock market, Mehar (2005) also gave the same result to the 
relationship between the concentration of shareholder structure and the distribution of profits.

However, some studies just pointed to an opposite of the hypothesis. Naceur (2006) conducted research with companies in Tunisia and found that the concentration of shareholders had no significant impact on their dividend payout ratios. This result is further supported by another conducted on the Morocco stock market by Aguenaou (2013). This study also fails to show the relationship between dividend policy and the level of ownership structure.

(2) How does the existence of large shareholders influence the dividend payout?

First, it is believed that enterprises, which have large state shareholders, are often stagnant, lack of transparency, lack of operation ideas, affected a lot by politic, have more social society activities, \& create jobs instead of focusing on business. Therefore, with the type of enterprise in which the State is a major shareholder, it was expected on the negative relationship of dividend payout ratios. Specifically, Nasr (2015) researched about a situation of profits sharing of equitized enterprises from 43 countries, and found that dividend policy had a negative relationship with share holding ratio of the State inside the companies. Shubiri (2012) studied about the profits sharing situation of businesses in Jordan, Wang (2011) with listed companies in China that also showed similar results with what the hypothesis set out.

Second, institutional investors, which are usually investment funds, tend to invest in longterm, \& look for company's sustainable growth. These funds will often be more transparent in management information than the others. In addition, to mitigate the problem of capital representatives, these institutional investors tend to pay high dividends to provide greater satisfaction to small shareholders. Short (2002) showed a positive relationship between the shareholding ratio of institutional investors and the company's dividend payout ratio, the sample of which is done by companies in the UK. Many other studies supported the hypothesis that major shareholders are institutional investors. Specifically, Masry (2008), Azzam (2010) with companies in Egypt, Elston (2004) with companies in Germany, Wiberg (2008) with companies in Sweden, Sharif (2010) with companies in Iran; they all pointed out the positive relationship between the dividend payout ratio and the shareholding percentage of institutional investors.

Third, if large shareholders are family members, this fact will lead to two common problems: lack of transparency of information and lack of managerial experience. Therefore, the initial impact can be seen as the company will be affected in terms of business efficiency leading to low profit sharing. The results of the empirical study show lots of evidence in favor of this argument. Nawaiseh (2013) researched on dividend policy of Jordanian businesses found that the ownership ratio of large family shareholders would have the opposite relationship with dividend payout ratio. Aguenaou (2011) also pointed out similar results when looking at listed companies on the Casablanca Stock Exchange in Morocco. Pindado (2011) researched about companies in the Euro area, \& found that the larger the company's ownership ratio, the higher the dividend payout ratio.

Fourth, some empirical results supported that if the company has major shareholders are foreign investors, which will prove that the transparency of the company's information is relatively good. Assuming that foreign investors are experienced in controlling corporate, it will attract more and more domestic and foreign investors. It will help to improve the business efficiency, then leading to a problem that the profits sharing ratio to shareholders will be high. A number of key studies have been conducted, such as Warrad (2012), which studied Jordan's dividend policy, found that there was a correlation between the shareholding ratio of large foreign shareholders and the dividend payout ratio of the business. The studies of Nawaiseh (2013) with companies in Jordan, Vinh (2014) with Vietnamese companies, Chai (2010) with companies in Korea, also gave results with the same trend, \& supported that the view of the hypothesis given is reasonable.

To sum up, with the theoretical frame that set out and illustrated by empirical findings, it is 
clear that the ownership structure influences the dividend policy of the firm; however, it may be different because of the ownership characteristics of the different business groups and the internal factors of the business. This paper sheds light to the relationship between ownership structure and dividend policy of Vietnamese firms. Specifically, we examine (1) the impact of ownership structure on the probability of dividend payment in Vietnam, and (2) whether ownership structure affects the decision of firms on the amount of dividend payment. Toward this end, we test the impact of the ownership structure in both aspects: ownership concentration and ownership types. Subsample tests are also used to examine whether the results are driven by companies listed in HOSE and HNX. To the best of our knowledge, this paper is one of the few studies examining the relationship between ownership structure and firms' financial decisions in Vietnam. Hence, our study contributes to the gap of knowledge on the effect of ownership structures on various aspects of firm management decisions in East Asia region.

\section{Research Design}

\subsection{Hypotheses}

The ownership structure affects the coporate dividend payout in 2 aspects: First, it is an ability of dividend payout, and second, it is the quantity of dividend payout of enterprise. The centralized ownership structure, the State ownership and domestic institutional ownership all tend to manage business operations and administrators more tightly. Thanatawee $(2013,2014)$ found that the higher level of centralized ownership, the State ownership and domestic institutional ownership ratios are, the bigger enterprise will willing to payout dividends. Sharma \& Wadwa (2013) also found that a positive correlation between institutional ownership and dividend policy of Indian companies. In conclusion, with the level of centralized ownership, institutional ownership and the State ownership, we established those hypotheses below:

- H1: the level of centralized ownership structure positively impacts on the ability of dividend payout and a dividend payment level of Vietnamese enterprises.

- H2: the State ownership has a positive effect on the ability of dividend payout and a dividend payment level of Vietnamese enterprises.

- H3: the institutional ownership affects positively the ability of dividend payout and a dividend payment level of Vietnamese enterprises.

The foreign ownership has an unobvious effect on dividend policy. On the one hand, an administrator who has an ownership, will tend to payout more dividends, minimize over-investment as well as help for him and other shareholders to receive income from free cash flow. On the other hand, the manager can also want to lower dividend payout in order to keep a large amount of cash, improve self-interest investments and cause damage for other small stockholders. While Ullah, Fida \& Khan (2012) found out a negative impact on management ownership rate with the ability of dividend payout, Nasrum (2015) showed a positive correlation. Therefore, we set up hypotheses:

- H4: the management ownership positively impacts on the ability of dividend payout and a dividend payment level of Vietnamese enterprises.

- H5: the management ownership has a negative effect on the ability of dividend payout and a dividend payment level of Vietnamese enterprises.

- In addition, some researches of Vietnamese market often can't find out the specific impact between the ownership structure and some aspects of financial decisions of business. Thereby, the authors set up hypotheses below:

- H6: the ownership structure does not impact on the ability of dividend payout and a dividend payment level of Vietnamese enterprises.

\subsection{Sample selection}

The research sample used by the authors is all non-financial companies listed on Ho Chi Minh City Stock Exchange (HOSE) and the Hanoi Stock Exchange (HNX). Financial companies such as banks, securities companies, investment funds and insurance companies that have distinct 
characteristics in ownership structure, are subject to separate management and use their own method of accounting are not considered in this study. The research sample collected during the 7year period from 2009 to 2015 includes 642 non-financial enterprises with a total of 4,494 observations based on panel data (company - year).

Data on the ownership rate of listed companies are mainly collected from two sources: the ownership database of listed companies of Vietstock.vn and the database of ownership of JSC Securities VNCIRECT. The databases of Vietstock.vn provide data on the volume of shares owned by the state, institutional investors, foreign investors, large shareholders and the board of directors. The databases of stock company VNDIRECT provides data on the total number of outstanding shares of listed companies in Vietnamese stock market. Besides, the authors consulted and used the data on the list and ownership rate of major shareholders from Stockbiz.vn database. Stock price data is also derived from historical price data of VNDIRECT Securities Joint Stock Company.

Financial data of enterprises listed on two Stock Exchanges are hand-collected from the consolidated financial statements by year from 2009 to 2015, including the data from the balance sheet, income statement, cash flow statement and note to financial statements. These reports are downloaded from the official website of the two Stock Exchanges: Ho Chi Minh Stock Exchange (www.hsx.vn) and Hanoi Stock Exchange (www.hnx.vn), particularly, in the section listed companies, shares and financial status of each stock code.

\subsection{Variables and measurement}

\subsubsection{Main dependent variables}

Distribution of profits in Vietnamese enterprises is mainly based on the distribution of dividends. Therefore, the authors used three main dependent variables to measure the profits distribution. As for the ability to pay dividends, the authors used the Dummy variable PAYOUT, the value is 1 if the company paid dividends in that year and 0 if the company does not pay dividends. In terms of dividend payment level, there are two main dependent variables: POR (Payout ratio) and DPS (Dividend per share).

\subsubsection{The variables of the ownership structure}

Based on previous studies, the authors used variables in the ownership structure of the enterprise as the main explanatory variable in regression models. Ownership variables were divided into two groups: the level of ownership concentration and the type of ownership structure.

\subsubsection{The level of ownership concentration}

Most previous studies used the total ownership rate of the five largest investors of the company (LARGEST). The authors applied this variable to reproduce the research results found in previous articles. In addition, this paper adding four indices less used in previous studies on the impact of the concentration ownership and financial decisions, the Herfindahl index (or H-index). The Herfindahl index or Herfindahl-Hirschman index $(\mathrm{HHI}$ or $\mathrm{H}$-index) is employed to measure the level of ownership concentration /dispersion for a given field. Initially, it was used to evaluate the level of competition in the market or an industry by the formula:

$$
H=\sum_{i=1}^{n} s_{i}^{2}
$$

In particular, $\mathrm{s}_{\mathrm{i}}$ is the market share of the company $\mathrm{i}$ in a certain markets/sectors. Herfindahl index takes the values from 0 to 1 , in which, the smaller the value, the more perfect the competition in the industry (each company occupies a small market share, no dominant or monopoly company). As $\mathrm{H}$-index is closer to 1 , the level of concentration in the industry is higher, indicating that the company occupies a dominant market share than the rest or monopoly companies.

Currently, in the researches of finance, $\mathrm{H}$-index is widely used to express the concentration dispersion of various areas. Hence, the authors apply this indicator to measure the level of concentration - dispersion of the ownership structure of listed companies. In particular, assume that 
in a listed company there are $\mathrm{n}$ major shareholders, with the volume of shares owned by each shareholder being share, Herfindahl index for all large stockholders will be computed by to the formula:

$$
H H I=\frac{\text { shares }_{1}^{2}+\text { shares }_{2}^{2}+\cdots+\text { shares }_{n}^{2}}{\left(\text { shares }_{1}+\text { shares }_{2}+\cdots+\text { shares }_{n}\right)^{2}}
$$

The authors calculated Herfindahl index in each company for all corporation's large shareholders (HINDEX_ALL), for the five biggest investors of the company (HINDEX_LARGE), institutional investors (HINDEX_INSTI) and foreign investors (HINDEX_FOREIGN).

\subsubsection{Types of ownership structures}

The researchers divide the types of ownership structures into the following groups: state ownership (STATE), institutional ownership (INSTITUTION), foreign ownership (FOREIGN), and managerial ownership (MANAGER). These variables are computed according to the total ownership rate of the types of ownership structures in the enterprise.

\subsubsection{Control variables}

In addition to the main explanatory variables mentioned above, the paper applies other important independent variables as control variables affecting the dependent variables. Specifically, the study employs the size of the company, the level of available fixed assets, the level of cash flow, the short-term solvency, the operating duration as a joint stock firm and the growth rate. SIZE, the size of the company, is measured by taking the natural logarithm of the firm's total assets. TANGIBILITY, calculated as dividing total net fixed asset value by total assets. CF_RATIO, cash flow factor, is the sum of the annual fixed asset depreciation and net profit to total asset. LIQUIDITY, short-term solvency, is measured by the proportion of money and cash equivalents in total assets. AGEINC, the number of years the company operates as a joint stock company. Finally, MB (Market to book ratio), computed as the market value to the book value ratio, reflects the growth of the business. The MB ratio is calculated by the market capitalization (the market value of the company) divided by the book value of the share capital (book value). This factor is large, which means that the market evaluates the growth prospects of the business good and vice versa, small coefficient means that the business has less opportunity of growth. Growth-stage companies often have high MB ratios, while companies in stable and mature stages often have low MB.

\subsection{Models and research methods}

\subsubsection{Probability models}

As for dividend policy, the authors researched initially on the effect of ownership structure on a probability of dividend payout in a year by conducting regressive the dependent variables PAYOUT, will be a dummy variable received value of 1 if a company payouts dividends in a year, and a variable will receive value of 0 if the company does not payout dividends. To conduct this regression, the simplest way is that carries out a common regression OLS. That model will be called as Linear Probability Model (LPM):

$\operatorname{Pr}(\text { PAYOUT }=1 \mid \text { OWNERSHIP, Controls })_{i, t}=\alpha_{0}+\alpha_{1}$ OWNERSHIP $_{i, t}+\beta^{\prime}$ Control $_{i, t}+\gamma_{i}+\mu_{t}+\varepsilon_{i, t}$

However, the LPM has few limitations in its structure leading to a using way to assess the probability of dividend payout is not really suitable. Firstly, the models use a regular linear regression, while the probability of paying dividends or not are only given in the range of $0 \%$ to $100 \%$. Using conventional OLS can lead to a condition when evaluating the impact, the probability of estimation from the model can be as low as $0 \%$ or higher than $100 \%$. Secondly, the regression factor from the LPM model is the slope of the line from the model. The change in the ownership rate of one unit or one standard deviation will be the same in all cases. For example, the effect of the concentration of ownership structure is measured by the state ownership ratio (STATE) for the probability of paying dividends as the percentage of ownership increases from $3 \%$ to $4 \%$, just like in 
the case of state ownership increasing from $50 \%$ to $51 \%$ from this model. Thus, the effect of ownership structure on dividend payoffs from LPM models does not adequately reflect the true impact.

To overcome these problems, the team performed probit regression and logistic regression, which is suitable for regressing dependent variables as binary variables (dummy). Probit and logistic distribution are limited to the range 0 to 1 , which is consistent with the study of the impact of the ownership structure on the probability of dividends paid by the firm. The probit and logit models have the equation as follows:

Probit model:

$\operatorname{Pr}(\text { PAYOUT }=1 \mid \text { OWNERSHIP }, \text { Controls })_{i, t}=\Phi\left(\alpha_{0}+\alpha_{1}\right.$ OWNERSHIP $_{i, t}+\beta^{\prime}$ Control $\left._{i, t}\right)$

Logistic model (logit)

$\operatorname{Pr}(\text { PAYOUT }=1 \mid \text { OWNERSHIP }, \text { Controls })_{i, t}=L\left(\alpha_{0}+\alpha_{1}\right.$ OWNERSHIP $i, t+\beta^{\prime}$ Control $\left._{i, t}\right)$

In particular, OWNERSHIP it is the ownership variable of company $\mathrm{i}$ in year $\mathrm{t}$ related to the level of concentration of ownership structure and types of ownership structure. Control it is the control variable of the company $\mathrm{i}$ in year $\mathrm{t}$.

\subsubsection{Tobit model with blocked dependent variables}

The next segment of the dividend policy that the authors would like to investigate is the level of dividends paid. The main dependent variable here is POR, dividend payout ratio. This dependent variable is characterized by a censored value. POR is calculated based on the total dividend payout on total after-tax profit. The profit from the business activities can be settled in two ways: retained for reinvestment in subsequent projects or paid in the form of dividends to shareholders. Therefore, the value of POR, though continuous, is blocked to the left at $0 \%$ (when the company does not pay dividends but retains all the profits for reinvestment) or right at the $100 \%$ (When the company pays the whole dividends and does not retain any profit). Thus, OLS regression is generally not appropriate for this dependent variable.

The study, therefore, used the Tobit regression model to look at the effect of ownership structure on the level of dividend payments. The Tobit model is particularly suited to regressions where the dependent variable is blocked as in this case.

POR $_{i, t}^{*}=\alpha_{0}+\alpha_{1}$ OWNERSHIP $P_{i, t}+\beta^{\prime}$ Control $_{i, t}+\gamma_{i}+\mu_{t}+\varepsilon_{i, t}$

In addition, the authors used an additional variable to measure the dividend payout level of the business, which is the number of dividends per DPS share to compare with the POR.

\section{Results and Discussion}

\subsection{Descriptive statistics}

The dividend, ownership structure and control variables are initially examined with exploratory data analysis based on the descriptive statistics and the results are shown in Table 1. The number of observations of the ownership structure of listed firms is not as much as those of the characteristics of the business. Among them, the most observations are the ownership of institutional investors and foreign investors (3828 observations). The Herfindahl index is smaller (the lowest is $3754 \mathrm{H}$ index for foreign investors and the highest is $3768 \mathrm{H}$-index for the total number of important investors), because the authors can only calculate $\mathrm{H}$-index if there is sufficient data on the ownership of key investors of listed companies in the two markets. Not all companies have foreign investors holding shares; therefore, the number of observations on $\mathrm{H}$-index of foreign investors is lower.

In terms of value, the average state ownership rate in the entire sample was $21.96 \%$ (median only $11.04 \%$ ), the largest was $79.56 \%$, which indicates that state ownership in listed companies is not high. Institutional investors tend to hold a higher proportion, at an average of $38.19 \%$ (with a median value of $40.87 \%$ ) and institutional ownership of foreign investors is high above $96 \%$. Foreign investors during the period 2009-2015 have average ownership rate in listed companies relatively low, reaching only $8.95 \%$ and the largest is $49 \%$. This is in line with government's 
regulations during this time on the limits of the room of foreign investors. It is remarkable that from $1^{\text {st }}$ September 2015, Decree 60/2015/ND-CP officially came into effect. This Decree amends and supplements Decree No. 58/2012/ND-CP detailing and guiding the implementation of a number of articles of the Law on Securities and the Law on Amendment, and adds several articles of the Law on Securities with the addition of $2 a$, which gives room for foreign investors up to $100 \%$. However, the data shows that at the end of 2015, the market and foreign investors have not yet conducted the adjustments in accordance with the new regulation of Decree 60, and the level of foreign ownership in listed enterprises maintains up to $49 \%$. The average managerial ownership rate is only $5.7 \%$, expressing that allowing managers to own shares to minimize interest conflicts between managers and shareholders remains relatively restricted. However, some companies allow their managers to own a large share proportion up to $55.5 \%$.

Table 1. Statistics describe the data

\begin{tabular}{|c|c|c|c|c|c|c|}
\hline Variables & Number of observations & Mean & Median & Standard Deviation & Maximum & Minimum \\
\hline \multicolumn{7}{|c|}{ Corporate ownership structure } \\
\hline STATE & 3827 & 0.2196 & 0.1104 & 0.2445 & 0.7956 & 0.0000 \\
\hline INSTITUTION & 3828 & 0.3819 & 0.4087 & 0.2605 & 0.9603 & 0.0000 \\
\hline FOREIGN & 3828 & 0.0895 & 0.0000 & 0.1637 & 0.4900 & 0.0000 \\
\hline MANAGER & 3827 & 0.0570 & 0.0062 & 0.1098 & 0.5550 & 0.0000 \\
\hline LARGEST & 3827 & 0.4669 & 0.5095 & 0.2268 & 0.9672 & 0.0000 \\
\hline HINDEX_ALL & 3768 & 0.3718 & 0.3068 & 0.2434 & 0.9999 & 0.0000 \\
\hline HINDEX_LARGE & 3761 & 0.4525 & 0.3834 & 0.2200 & 0.9999 & 0.0000 \\
\hline HINDEX_INSTI & 3761 & 0.5940 & 0.5741 & 0.3120 & 1.0000 & 0.0000 \\
\hline HINDEX FOREIGN & 3754 & 0.2964 & 0.0000 & 0.3729 & 1.0000 & 0.0000 \\
\hline \multicolumn{7}{|l|}{ Corporate statistics } \\
\hline CS & 4257 & 0.5080 & 0.5315 & 0.2226 & 0.9417 & 0.0419 \\
\hline STD & 4258 & 0.4042 & 0.3947 & 0.2109 & 0.9013 & 0.0291 \\
\hline LTD & 4260 & 0.1050 & 0.0365 & 0.1462 & 0.6388 & 0.0000 \\
\hline BANKD & 4260 & 0.1673 & 0.1186 & 0.1739 & 0.6772 & 0.0000 \\
\hline INVEST & 4259 & 0.0551 & 0.0254 & 0.0784 & 0.4292 & 0.0000 \\
\hline PAYOUT & 4494 & 0.6987 & 1.0000 & 0.4589 & 1.0000 & 0.0000 \\
\hline POR & 3405 & 0.2102 & 0.1752 & 0.2075 & 0.9911 & 0.0000 \\
\hline DPS & 4046 & 1076 & 800 & 1343 & 21000 & 0.0000 \\
\hline ROA & 4260 & 0.0654 & 0.0481 & 0.0750 & 0.3611 & -0.1374 \\
\hline ROE & 4256 & 0.1333 & 0.1210 & 0.1401 & 0.6867 & -0.3569 \\
\hline TOBINQ & 4258 & 0.9504 & 0.8878 & 0.4666 & 3.3192 & 0.1021 \\
\hline SIZE & 4261 & 26.8282 & 26.7534 & 1.4547 & 30.7261 & 23.5302 \\
\hline TANGIBILITY & 4261 & 0.2128 & 0.1425 & 0.2072 & 0.8707 & 0.0003 \\
\hline CF_RATIO & 4258 & 0.1017 & 0.0783 & 0.1045 & 0.6285 & -0.1122 \\
\hline AGEINC & 4449 & 9.0967 & 9.0000 & 4.1373 & 26.0000 & 1.0000 \\
\hline $\mathrm{MB}$ & 3604 & 1.0253 & 0.8246 & 0.7726 & 4.4765 & 0.1186 \\
\hline LIQUIDITY & 4261 & 0.1030 & 0.0596 & 0.1170 & 0.5852 & 0.0007 \\
\hline
\end{tabular}

Regarding the concentration ownership level, the average ownership of the 5 biggest investors was $46.69 \%$ with the median level of $50.95 \%$ and the highest value of $96.72 \%$. This shows that, in many companies, stock ownership is concentrated in the hands of the largest investors. Herfindahl index data describe a clearer picture of the level of ownership concentration. The $\mathrm{H}$-index of all major shareholders has an average of less than 0.5. This shows that the share ownership in Vietnamese enterprises on average is not too concentrated but not really dispersal. The value of the $\mathrm{H}$-index of institutional investors at 0.594 indicates that institutional investors are more likely to be concentrated in the hands of large institutional investors. Meanwhile, the low value of $\mathrm{H}$-indexes of foreign investors $(0.2964)$ specifies that the allocation of ownership rate among investors is more equal.

For variable characteristics of the business, the debt ratio of listed companies in Vietnam tends to be relatively high (over $50 \%$ for mean and median values, and up to over $90 \%$ ). Debt is 
mainly short-term debt with a short-term debt to total assets ratio of approximately $40 \%$. At the same time, the long-term debt to total assets ratio is averagely $10.50 \%$. Although there are companies with a high bank loan ratio of over $67 \%$, listed firms have a bank loan to total asset ratio of over $16.73 \%$. This expresses that listed firms can access other sources of debt (for example, from bond issuance) and are not too dependent on bank loans.

On average, listed firms have 9 years of operation as joint stock companies. The average Tobin's $q$ and MB ratios at approximately 1 indicate show that, companies listed on the two stick exchanges of Vietnam are mature firms (market value is close to book value). Other variables also indicate that. For example, the rate of cash holdings is low (average $10.30 \%$ with a median of approximately $6 \%$ ); the probability of paying a average dividend is high $(69.87 \%)$; average investment rate is low (5.51\%); average asset size is 448 billion dong (natural logarithm of 26.8282) with the highest level of 22 trillion dong.

\subsection{The probability of dividend payout}

The regression effect of the degree of concentration of ownership structure on the probability of dividends payment is shown in Table 3. It can be seen that the results of all three models of probability are relatively uniform. The concentration of ownership structure is positively correlated and statistically significant (at 1\%) with the largest shareholder-owned, the $\mathrm{H}$-index of all major investors and the $\mathrm{H}$-index of the largest shareholders in the business. The $\mathrm{H}$-index of institutional investors and foreign investors has no statistically significant impact. In terms of economic meaning, with the LPM model, equation (2), a one standard deviation of HINDEX_ALL led to increase $3.54 \%$ the dividends payout ability during the year. Thus, this result is consistent with the $\mathrm{H} 1$ of the study: the degree of ownership concentration has the same impact as the probability of paying dividends of listed companies.

Table 2. The centralized ownership structure level \& the probability of dividends

\begin{tabular}{|c|c|c|c|c|c|c|c|c|c|c|c|c|c|c|c|}
\hline \multirow{2}{*}{$\begin{array}{l}\text { Dependent } \\
\text { variable: } \\
\text { PAYOUT }\end{array}$} & \multicolumn{5}{|c|}{ LPM model } & \multicolumn{5}{|c|}{ Probit model } & \multicolumn{5}{|c|}{ Logistic model } \\
\hline & (1) & (2) & (3) & (4) & (5) & (6) & (7) & (8) & (9) & (10) & (11) & (12) & (13) & (14) & (15) \\
\hline Constant & $\begin{array}{c}-0.0376 \\
(-0.16)\end{array}$ & $\begin{array}{c}-0.0839 \\
(-0.34)\end{array}$ & $\begin{array}{c}-0.0868 \\
(-0.35)\end{array}$ & $\begin{array}{c}-0.1821 \\
(-0.71)\end{array}$ & $\begin{array}{c}-0.1111 \\
(-0.45)\end{array}$ & $\begin{array}{c}-1.9990^{\star \star} \\
(-2.45)\end{array}$ & $\begin{array}{c}-2.1363^{\star \star \star} \\
(-2.58)\end{array}$ & $\begin{array}{c}-2.1213^{\star \star} \\
(-2.56)\end{array}$ & $\begin{array}{c}-2.4823^{\star \star \star} \\
(-2.88)\end{array}$ & 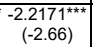 & $\begin{array}{c}-3.6390^{\star \star \star} \\
(-2.60)\end{array}$ & $\begin{array}{c}-3.8286^{\star \star \star} \\
(-2.72)\end{array}$ & $\begin{array}{c}-3.8432^{\star \star \star} \\
(-2.71)\end{array}$ & $\begin{array}{c}-4.4492^{* * *} \\
(-3.03)\end{array}$ & $\begin{array}{c}-4.0108^{* \star \star} \\
(-2.81)\end{array}$ \\
\hline LARGEST & $\begin{array}{c}0.2074^{\star \star \star *} \\
(4.95)\end{array}$ & & & & & $\begin{array}{c}0.6381^{\star \star \star} \\
(4.56)\end{array}$ & & & & & $\begin{array}{c}1.0760^{\star \star \star} \\
(4.55)\end{array}$ & & & & \\
\hline $\begin{array}{l}\text { HINDEX } \\
\text { ALL }\end{array}$ & & $\begin{array}{c}0.1454^{\star \star \star *} \\
(2.90)\end{array}$ & & & & & $\begin{array}{c}0.4679^{\star \star \star} \\
(2.79)\end{array}$ & & & & & $\begin{array}{c}0.8306^{\star \star \star} \\
(2.87)\end{array}$ & & & \\
\hline $\begin{array}{l}\text { HINDEX } \\
\text { LARGE }\end{array}$ & & & $\begin{array}{c}0.1676^{\star \star \star} \\
(3.02)\end{array}$ & & & & & $\begin{array}{c}0.5503^{\star \star \star *} \\
(2.97)\end{array}$ & & & & & $\begin{array}{c}0.9659^{\star * *} \\
(3.02)\end{array}$ & & \\
\hline $\begin{array}{l}\text { FIINDEX } \\
\text { FOREIGN }\end{array}$ & & & & & $\begin{array}{c}-0.0120 \\
(-0.40)\end{array}$ & & & & & $\begin{array}{c}-0.0470 \\
(-0.49)\end{array}$ & & & & & $\begin{array}{c}-0.0648 \\
(-0.41)\end{array}$ \\
\hline S̈IZE & $\begin{array}{c}0.0104 \\
(1.23)\end{array}$ & $\begin{array}{c}0.0134 \\
(1.53)\end{array}$ & $\begin{array}{l}0.0128 \\
(1.45)\end{array}$ & $\begin{array}{c}0.0178^{\star \star} \\
(1.97)\end{array}$ & $\begin{array}{c}0.0162^{*} \\
(1.83)\end{array}$ & $\begin{array}{c}0.0374 \\
(1.28)\end{array}$ & $\begin{array}{c}0.0462 \\
(1.56)\end{array}$ & $\begin{array}{c}0.0432 \\
(1.45)\end{array}$ & $\begin{array}{c}0.0616^{\star \star} \\
(2.03)\end{array}$ & $\begin{array}{c}0.0556^{\star} \\
(1.86)\end{array}$ & $\begin{array}{l}0.0723 \\
(1.45)\end{array}$ & $\begin{array}{c}0.0846^{\star} \\
(1.68)\end{array}$ & $\begin{array}{c}0.0810 \\
(1.60)\end{array}$ & $\begin{array}{l}0.1123^{\star \star} \\
(2.19)\end{array}$ & $\begin{array}{c}0.1023^{\star *} \\
(2.01)\end{array}$ \\
\hline TANGIBILITY & $\begin{array}{l}0.0030 \\
(0.05)\end{array}$ & $\begin{array}{c}-0.0086 \\
(-0.15)\end{array}$ & $\begin{array}{c}-0.0127 \\
(-0.22)\end{array}$ & $\begin{array}{c}0.0124 \\
(0.21)\end{array}$ & $\begin{array}{c}0.0215 \\
(0.37)\end{array}$ & $\begin{array}{c}-0.0946 \\
(-0.51)\end{array}$ & $\begin{array}{c}-0.1206 \\
(-0.64)\end{array}$ & $\begin{array}{c}-0.1363 \\
(-0.72)\end{array}$ & $\begin{array}{c}-0.0509 \\
(-0.27)\end{array}$ & $\begin{array}{c}-0.0221 \\
(-0.12)\end{array}$ & $\begin{array}{c}-0.1994 \\
(-0.63)\end{array}$ & $\begin{array}{c}-0.2674 \\
(-0.83)\end{array}$ & $\begin{array}{c}-0.2904 \\
(-0.90)\end{array}$ & $\begin{array}{c}-0.1386 \\
(-0.43)\end{array}$ & $\begin{array}{c}-0.0793 \\
(-0.24)\end{array}$ \\
\hline CF_RATIO & $\begin{array}{c}0.2485^{\star} \\
(1.96)\end{array}$ & $\begin{array}{c}0.2369^{\star} \\
(1.75)\end{array}$ & $\begin{array}{c}0.2379^{\star} \\
(1.76)\end{array}$ & $\begin{array}{c}0.2494^{\star} \\
(1.85)\end{array}$ & $\begin{array}{c}0.2274^{\star} \\
(1.68)\end{array}$ & $\begin{array}{c}1.5467^{\star \star} \\
(2.46)\end{array}$ & $\begin{array}{c}1.5369^{\star *} \\
(2.35)\end{array}$ & $\begin{array}{c}1.5209^{\star *} \\
(2.34)\end{array}$ & $\begin{array}{c}1.5954^{\star *} \\
(2.42)\end{array}$ & $\begin{array}{c}1.5047^{\star \star} \\
(2.27)\end{array}$ & $\begin{array}{c}3.0821^{\star \star} \\
(2.23)\end{array}$ & $\begin{array}{c}3.0469^{\star *} \\
(2.15)\end{array}$ & $\begin{array}{c}3.0060^{\star *} \\
(2.16)\end{array}$ & $\begin{array}{c}3.2363^{\star \star} \\
(2.22)\end{array}$ & $\begin{array}{c}2.9849^{\star \star} \\
(2.09)\end{array}$ \\
\hline LIQUIDITY & $\begin{array}{c}0.5237^{\star \star \star} \\
(6.76)\end{array}$ & $\begin{array}{c}0.5223^{\star \star \star} \\
(6.51)\end{array}$ & $\begin{array}{c}0.5123^{\star \star \star} \\
(6.32)\end{array}$ & $\begin{array}{c}0.5426^{\star \star \star} \\
(6.74)\end{array}$ & $\begin{array}{c}0.5303^{\star \star \star \star} \\
(6.52)\end{array}$ & $\begin{array}{c}2.1783^{\star \star \star} \\
(5.82)\end{array}$ & $\begin{array}{c}2.2506^{\star \star \star} \\
(5.84)\end{array}$ & $\begin{array}{c}2.1637^{\star \star \star} \\
(5.66)\end{array}$ & $\begin{array}{c}2.3086^{\star \star \star} \\
(5.98)\end{array}$ & $\begin{array}{c}2.2042^{\star \star \star} \\
(5.79)\end{array}$ & $\begin{array}{c}3.9053^{\star \star \star} \\
(5.37)\end{array}$ & $\begin{array}{c}3.9899^{\star \star \star \star} \\
(5.35)\end{array}$ & $\begin{array}{c}3.8598^{\star \star \star} \\
(5.21)\end{array}$ & $\begin{array}{c}4.1053^{\star \star \star} \\
(5.49)\end{array}$ & $\begin{array}{c}3.9363^{\star \star \star} \\
(5.33)\end{array}$ \\
\hline ROE & $\begin{array}{c}0.8337^{\star \star \star \star} \\
(8.08)\end{array}$ & $\begin{array}{c}0.8624^{\star \star \star} \\
(8.05)\end{array}$ & $\begin{array}{c}0.8669^{\star \star \star} \\
(8.13)\end{array}$ & $\begin{array}{c}0.8604^{\star \star \star} \\
(8.00)\end{array}$ & $\begin{array}{c}0.8916^{\star \star \star \star} \\
(8.35)\end{array}$ & $\begin{array}{c}2.6332^{\star \star \star} \\
(5.63)\end{array}$ & $\begin{array}{c}2.6855^{\star \star \star} \\
(5.57)\end{array}$ & $\begin{array}{c}2.7097^{\star \star \star \star} \\
(5.65)\end{array}$ & $\begin{array}{c}2.6739^{\star \star \star \star} \\
(5.53)\end{array}$ & $\begin{array}{c}2.8107^{\star \star \star \star} \\
(5.75)\end{array}$ & $\begin{array}{c}4.8987^{\star \star \star} \\
(4.85)\end{array}$ & $\begin{array}{c}5.0603^{\star \star \star \star} \\
(4.91)\end{array}$ & $\begin{array}{c}5.0953^{* \star \star *} \\
(5.01)\end{array}$ & $\begin{array}{c}4.9741^{\star \star \star} \\
(4.75)\end{array}$ & $\begin{array}{c}5.2872^{\star \star \star} \\
(5.00)\end{array}$ \\
\hline MB & $\begin{array}{c}-0.0021 \\
(-0.15)\end{array}$ & $\begin{array}{l}0.0047 \\
(0.32)\end{array}$ & $\begin{array}{l}0.0038 \\
(0.26)\end{array}$ & $\begin{array}{l}0.0026 \\
(0.18)\end{array}$ & $\begin{array}{r}-0.0000 \\
(-0.00)\end{array}$ & $\begin{array}{c}0.0303 \\
(0.51)\end{array}$ & $\begin{array}{c}0.0526 \\
(0.88)\end{array}$ & $\begin{array}{c}0.0505 \\
(0.85)\end{array}$ & $\begin{array}{c}0.0438 \\
(0.73)\end{array}$ & $\begin{array}{c}0.0322 \\
(0.54)\end{array}$ & $\begin{array}{c}0.0360 \\
(0.33)\end{array}$ & $\begin{array}{c}0.0764 \\
(0.70)\end{array}$ & $\begin{array}{c}0.0726 \\
(0.67)\end{array}$ & $\begin{array}{c}0.0616 \\
(0.56)\end{array}$ & $\begin{array}{l}0.0419 \\
(0.38)\end{array}$ \\
\hline $\begin{array}{l}\text { Controlling for } \\
\text { The fixed sectionimpa }\end{array}$ & Yes & Yes & Yes & Yes & Ye & Yes & Yes & $\mathrm{Ye}$ & Yes & $\mathrm{Ye}$ & Ye & Ye & Ye & Yes & Yes \\
\hline The fixed year ir & Yes & Yes & Yes & Yes & Yes & Yes & Yes & Yes & Yes & Yes & Yes & Yes & Yes & Yes & Yes \\
\hline No. of observations & 3592 & 3523 & 3517 & 3515 & 3510 & 3592 & 3523 & 3517 & 3515 & 3510 & 3592 & 3523 & 3517 & 3515 & 3510 \\
\hline$R^{2} /$ Pseudo $R^{2}$ & 0.1822 & 0.1811 & 0.1804 & 0.1760 & 0.1756 & 0.1755 & 0.1751 & 0.1738 & 0.1708 & 0.1697 & 0.1813 & 0.1815 & 0.1803 & 0.1769 & 0.1761 \\
\hline
\end{tabular}


Table 3. The type of ownership structure \& the probability of dividends.

\begin{tabular}{|c|c|c|c|c|c|c|c|c|c|c|c|c|c|c|c|}
\hline \multirow{2}{*}{$\begin{array}{l}\text { Dependent } \\
\text { variable: } \\
\text { PAYOUT }\end{array}$} & \multicolumn{5}{|c|}{ LPM model } & \multicolumn{5}{|c|}{ Probit model } & \multicolumn{5}{|c|}{ Logistic model } \\
\hline & (1) & (2) & (3) & (4) & (5) & (6) & (7) & (8) & (9) & (10) & (11) & (12) & (13) & (14) & (15) \\
\hline Constant & $\begin{array}{c}0.0601 \\
(0.25)\end{array}$ & $\begin{array}{c}0.1025 \\
(0.44)\end{array}$ & $\begin{array}{c}-0.0946 \\
(-0.40)\end{array}$ & $\begin{array}{c}-0.0491 \\
(-0.20)\end{array}$ & $\begin{array}{c}0.1214 \\
(0.52)\end{array}$ & $\begin{array}{r}-1.6535^{\star \star} \\
(-2.00)\end{array}$ & $\begin{array}{r}-1.5445^{*} \\
(-1.88)\end{array}$ & $\begin{array}{c}-2.1855^{\star \star} \\
(-2.67)\end{array}$ & $\begin{array}{c}{ }^{*}-2.0602^{\star \star} \\
(-2.50)\end{array}$ & $\begin{array}{c}-1.4537^{*} \\
(-1.76)\end{array}$ & $\begin{array}{c}-3.0850^{\star *} \\
(-2.15)\end{array}$ & $\begin{array}{c}-2.8790^{\star \star} \\
(-2.04)\end{array}$ & $\begin{array}{c}-3.9743^{* \star \star} \\
(-2.83)\end{array}$ & $\begin{array}{c}-3.7642^{* \star \star} \\
(-2.66)\end{array}$ & $\begin{array}{c}-2.7290^{*} \\
(-1.91)\end{array}$ \\
\hline STATE & $\begin{array}{c}0.3115^{\star \star \star} \\
(7.37)\end{array}$ & & & & $\begin{array}{c}0.2022^{\star \star \star \star} \\
(3.78)\end{array}$ & $\begin{array}{c}1.0691^{\star \star \star} \\
(7.14)\end{array}$ & & & & $\begin{array}{c}0.7472^{\star \star \star} \\
(4.05)\end{array}$ & $\begin{array}{c}1.8386^{* * *} \\
(7.11)\end{array}$ & & & & $\begin{array}{c}1.2970^{\star \star \star \star} \\
(4.11)\end{array}$ \\
\hline INSTITUTION & & $\begin{array}{c}0.2912^{\star \star \star} \\
(7.38)\end{array}$ & & & $\begin{array}{c}0.1900^{\star \star \star *} \\
(3.68)\end{array}$ & & $\begin{array}{c}0.9284^{\star \star \star \star} \\
(6.88)\end{array}$ & & & $\begin{array}{c}0.5818^{\star * \star} \\
(3.43)\end{array}$ & & $\begin{array}{c}1.5892^{* * *} \\
(6.89)\end{array}$ & & & $\begin{array}{c}0.9793^{* * *} \\
(3.43)\end{array}$ \\
\hline FOREIGN & & & $\begin{array}{c}-0.0207 \\
(-0.21)\end{array}$ & & $\begin{array}{c}0.0109 \\
(0.11)\end{array}$ & & & $\begin{array}{c}-0.0554 \\
(-0.17)\end{array}$ & & $\begin{array}{c}0.0560 \\
(0.17)\end{array}$ & & & $\begin{array}{c}-0.1142 \\
(-0.19)\end{array}$ & & \\
\hline MÂNAGER & & & & $\begin{array}{c}-0.1976^{\star \star} \\
(-2.29)\end{array}$ & $\begin{array}{c}0.0601 \\
(0.68)\end{array}$ & & & & $\begin{array}{c}-0.5610^{* *} \\
(-2.15)\end{array}$ & $\begin{array}{c}0.2565 \\
(0.95)\end{array}$ & & & & $\begin{array}{c}-0.9901^{* *} \\
(-2.25)\end{array}$ & $\begin{array}{l}0.3741 \\
(0.83)\end{array}$ \\
\hline SIZE & $\begin{array}{l}0.0083 \\
(0.97)\end{array}$ & $\begin{array}{l}0.0058 \\
(0.69)\end{array}$ & $\begin{array}{c}0.0154^{\star} \\
(1.78)\end{array}$ & $\begin{array}{c}0.0142 \\
(1.64)\end{array}$ & $\begin{array}{c}0.0049 \\
(0.58)\end{array}$ & $\begin{array}{c}0.0284 \\
(0.95)\end{array}$ & $\begin{array}{l}0.0215 \\
(0.73)\end{array}$ & $\begin{array}{c}0.0536^{*} \\
(1.83)\end{array}$ & $\begin{array}{c}0.0502^{*} \\
(1.70)\end{array}$ & $\begin{array}{c}0.0169 \\
(0.57)\end{array}$ & $\begin{array}{c}0.0576 \\
(1.12)\end{array}$ & & $\begin{array}{c}0.1002^{\star \star} \\
(2.00)\end{array}$ & $\begin{array}{r}0.05 \\
(1 .\end{array}$ & $\begin{array}{c}0.0379 \\
(0.74)\end{array}$ \\
\hline TANGIBILITY & $\begin{array}{c}-0.0373 \\
(-0.67)\end{array}$ & $\begin{array}{c}-0.0158 \\
(-0.28)\end{array}$ & $\begin{array}{l}0.0205 \\
(0.36)\end{array}$ & $\begin{array}{c}0.0177 \\
(0.31)\end{array}$ & $\begin{array}{c}-0.0399 \\
(-0.72)\end{array}$ & $\begin{array}{c}-0.2643 \\
(-1.41)\end{array}$ & $\begin{array}{c}-0.1710 \\
(-0.92)\end{array}$ & $\begin{array}{l}-0.0365 \\
(-0.19)\end{array}$ & $\begin{array}{c}-0.0439 \\
(-0.23)\end{array}$ & $\begin{array}{c}-0.2769 \\
(-1.48)\end{array}$ & $\begin{array}{c}-0.5138 \\
(-1.61)\end{array}$ & $\begin{array}{r}-0.3447 \\
(-1.08)\end{array}$ & $\begin{array}{c}-0.1081 \\
(-0.34)\end{array}$ & $\begin{array}{c}-0.1207 \\
(-0.38)\end{array}$ & $\begin{array}{c}-0.5360^{*} \\
(-1.67)\end{array}$ \\
\hline CF_RATIO & $\begin{array}{c}0.2310^{\star} \\
(1.83)\end{array}$ & $\begin{array}{c}0.2153^{\star} \\
(1.69)\end{array}$ & $\begin{array}{c}0.2816^{\star *} \\
(2.19)\end{array}$ & $\begin{array}{c}0.2738^{\star * \star} \\
(2.12)\end{array}$ & $\begin{array}{c}0.2077^{\star} \\
(1.65)\end{array}$ & $\begin{array}{c}1.5510^{* \star} \\
(2.48)\end{array}$ & $\begin{array}{c}1.4398^{* *} \\
(2.31)\end{array}$ & $\begin{array}{c}1.6886^{\star \star \star} \\
(2.63)\end{array}$ & $\begin{array}{c}1.6567^{\star \star \star} \\
(2.59)\end{array}$ & $\begin{array}{c}1.4507^{* \star} \\
(2.34)\end{array}$ & $\begin{array}{c}3.0502^{\star *} \\
(2.29)\end{array}$ & $\begin{array}{c}2.8628^{\star \star *} \\
(2.15)\end{array}$ & $\begin{array}{c}3.4471^{\star \star} \\
(2.42)\end{array}$ & $\begin{array}{c}3.3624^{\star \star} \\
(2.40)\end{array}$ & $\begin{array}{c}2.8477^{\star \star} \\
(2.16)\end{array}$ \\
\hline LIQUIDITY & $\begin{array}{c}0.4929^{\star \star \star \star} \\
(6.50)\end{array}$ & $\begin{array}{c}0.4711^{\star \star \star} \\
(6.14)\end{array}$ & $\begin{array}{c}0.5382^{\star \star \star \star} \\
(6.83)\end{array}$ & $\begin{array}{c}{ }^{*} 0.5190^{\star \star \star *} \\
(6.61)\end{array}$ & $\begin{array}{c}{ }^{*} 0.4706^{\star \star \star} \\
(6.22)\end{array}$ & $\begin{array}{c}2.0425^{\star \star \star} \\
(5.60)\end{array}$ & $\begin{array}{c}{ }^{*} .9951^{\star \star \star} \\
(5.37)\end{array}$ & $\begin{array}{c}2.2246^{\star \star \star} \\
(5.93)\end{array}$ & $\begin{array}{c}2.1672^{\star \star \star} \\
(5.80)\end{array}$ & $\begin{array}{c}1.9784^{\star \star \star} \\
(5.41)\end{array}$ & $\begin{array}{c}3.6083^{\star \star \star \star} \\
(5.15)\end{array}$ & $\begin{array}{c}3.5310^{\star \star \star \star} \\
(4.93)\end{array}$ & $\begin{array}{c}3.9902^{\star \star \star *} \\
(5.50)\end{array}$ & $\begin{array}{c}3.8716^{\star * \star} \\
(5.38)\end{array}$ & $\begin{array}{c}3.4836^{\star \star \star \star} \\
(4.95)\end{array}$ \\
\hline AGE_INC & $\begin{array}{c}0.0098^{\star \star *} \\
(3.44)\end{array}$ & $\begin{array}{c}0.0103^{\star \star \star} \\
(3.66)\end{array}$ & $\begin{array}{c}0.0094^{\star \star \star *} \\
(3.26)\end{array}$ & $\begin{array}{c}{ }^{*} 0.0097^{\star \star \star \star} \\
(3.37)\end{array}$ & $\begin{array}{c}{ }^{\star} 0.0102^{\star \star \star *} \\
(3.58)\end{array}$ & $\begin{array}{c}0.0346^{\star \star \star} \\
(3.42)\end{array}$ & $\begin{array}{c}{ }^{*} 0.0355^{\star \star \star \star} \\
(3.48)\end{array}$ & $\begin{array}{c}0.0313^{\star \star \star} \\
(3.11)\end{array}$ & $\begin{array}{c}0.0325^{\star \star \star *} \\
(3.21)\end{array}$ & $\begin{array}{c}* 0.0357^{\star \star \star \star} \\
(3.49)\end{array}$ & $\begin{array}{c}0.0568^{* \star \star \star} \\
(3.23)\end{array}$ & $\begin{array}{c}0.0576^{\star \star \star \star} \\
(3.26)\end{array}$ & $\begin{array}{c}0.0512^{* * \star} \\
(2.96)\end{array}$ & $\begin{array}{c}0.0534^{* \star \star} \\
(3.06)\end{array}$ & $\begin{array}{c}* 0.0583^{\star \star \star \star} \\
(3.28)\end{array}$ \\
\hline ROE & $\begin{array}{c}0.8033^{\star \star \star *} \\
(7.99)\end{array}$ & $\begin{array}{c}0.8182^{\star \star \star} \\
(7.93)\end{array}$ & $\begin{array}{c}0.8357^{\star \star \star \star} \\
(8.13)\end{array}$ & $\begin{array}{c}* 0.8394^{\star \star \star *} \\
(8.09)\end{array}$ & $\begin{array}{c}{ }^{\star} 0.8021^{\star \star \star \star} \\
(7.89)\end{array}$ & $\begin{array}{c}2.5347^{\star \star \star \star} \\
(5.54)\end{array}$ & $\begin{array}{c}{ }^{*} 2.6029^{\star \star \star \star} \\
(5.58)\end{array}$ & $\begin{array}{c}2.6083^{\star \star \star} \\
(5.59)\end{array}$ & $\begin{array}{c}2.6142^{\star \star \star *} \\
(5.59)\end{array}$ & $\begin{array}{c}{ }^{\star} 2.5492^{\star \star \star} \\
(5.55)\end{array}$ & $\begin{array}{c}4.7146^{\star \star \star \star} \\
(4.90)\end{array}$ & $\begin{array}{c}4.8537^{\star \star \star \star} \\
(4.94)\end{array}$ & $\begin{array}{c}4.7974^{* * \star} \\
(4.76)\end{array}$ & $\begin{array}{c}4.8427^{\star \star \star \star} \\
\quad(4.83)\end{array}$ & $\begin{array}{c}{ }^{*} 4.7500^{\star \star \star \star} \\
(4.91)\end{array}$ \\
\hline MB & $\begin{array}{c}0.0070 \\
(0.52)\end{array}$ & $\begin{array}{l}0.0010 \\
(0.07)\end{array}$ & $\begin{array}{c}0.0010 \\
(0.07)\end{array}$ & $\begin{array}{l}0.0014 \\
(0.10)\end{array}$ & $\begin{array}{l}0.0049 \\
(0.36)\end{array}$ & $\begin{array}{l}0.0707 \\
(1.24)\end{array}$ & $\begin{array}{l}0.0449 \\
(0.74)\end{array}$ & $\begin{array}{l}0.0415 \\
(0.71)\end{array}$ & $\begin{array}{l}0.0435 \\
(0.73)\end{array}$ & $\begin{array}{l}0.0632 \\
(1.10)\end{array}$ & $\begin{array}{l}0.1096 \\
(1.04)\end{array}$ & $\begin{array}{l}0.0640 \\
(0.58)\end{array}$ & $\begin{array}{c}0.0550 \\
(0.52)\end{array}$ & $\begin{array}{c}0.0598 \\
(0.55)\end{array}$ & $\begin{array}{l}0.0966 \\
(0.91)\end{array}$ \\
\hline & & & & & & & & & & & & & & & \\
\hline & $\begin{array}{l}\text { Yes } \\
\text { Yes }\end{array}$ & $\begin{array}{l}\text { Yes } \\
\text { Yes }\end{array}$ & & Yes & & $\begin{array}{l}\text { Yes } \\
\text { Yes }\end{array}$ & Yes & & & & & Yes & $Y e$ & Yes & $\begin{array}{l}\text { Yes } \\
\text { Yes }\end{array}$ \\
\hline act & $\begin{array}{c}\text { Yes } \\
3592\end{array}$ & $\begin{array}{c}\text { Yes } \\
3593\end{array}$ & & $\begin{array}{c}\text { Yes } \\
3592\end{array}$ & $\begin{array}{c}\text { Yes } \\
3592\end{array}$ & $\begin{array}{l}\text { Yes } \\
3592\end{array}$ & $\begin{array}{c}\text { Yes } \\
3593\end{array}$ & $\begin{array}{r}Y \epsilon \\
35\end{array}$ & $\begin{array}{c}\text { Yes } \\
3592\end{array}$ & $\begin{array}{r}Y e \\
359\end{array}$ & $\begin{array}{c}\text { Yes } \\
3592\end{array}$ & $\begin{array}{r}Y e \\
359\end{array}$ & $\begin{array}{l}Y e \\
35\end{array}$ & $\begin{array}{c}\text { Yes } \\
3592\end{array}$ & $\begin{array}{c}\text { Yes } \\
3592\end{array}$ \\
\hline $\mathrm{R}^{2} /$ sseudo $\mathrm{R}^{2}$ & 0.1959 & 0.1957 & 0.1734 & 0.1748 & 0.2011 & 0.1897 & 0.1875 & 0.1685 & 0.1695 & 0.1943 & 0.1955 & 0.1933 & 0.1745 & 0.1757 & 0.2001 \\
\hline
\end{tabular}

Table 3 presents the regression results of the probability of paying dividends models of listed companies in Vietnam by types of ownership structure. The State ownership and ownership of institutional investors' ratios were positively and statistically significant in all three models $(1 \%$ significance). This is in line with the hypotheses $\mathrm{H} 1, \mathrm{H} 2$ and $\mathrm{H} 3$ that the authors published in Section 3. The study did not find significant impact of foreign shareholders ownership on the probability of paying dividends. For the ownership of managers, despite a negative and statistically significant $5 \%$ in equation (1), in equation (2), in the presence of all remaining ownership ratios, the ownership ratio of managers has no statistically significant impact on the probability of dividends paid by the business.

To sum up, through the research on the probability of paying dividends, it can be seen that the degree of concentration of ownership structure, the State's ownership and ownership of institutional investors have a positive effect with respect to decision making to pay dividends of listed companies on the Vietnam stock market.

\subsection{The dividend payout level}

In this section, the study used two measurement targets to calculate corporate dividends, POR and DPS. The characteristics of both indexes are that these are two censored indicators. POR is blocked by $0 \%$ and $100 \%$ and DPS is blocked to the left at 0 dong / stock. As a result, the results from the OLS regression will not really reflect the impact of the ownership structure on the level of enterprise dividends. Therefore, using Tobit regression will be consistent with the two indicators mentioned in Section 3.

The study conducted regress the Tobit impacting the degree of concentration of ownership structure and types of ownership structure on the dividend payout ratio POR with the blocked left and right dividends target on each DPS stock with left-stop levels. The results for the degree of ownership structure concentration was shown in Table 4 and the results of the types of ownership structure in Table 5. The regression models with dependent variable from (1) to (5) are the DPS and the ones from (6) to (10) with the dependent variable are the POR

Similar to the probability of dividends payout, we found a positive and statistically significant correlation between the degree of concentration of ownership structure, the State-owned and the ownership of Institutional investors with dividends paid level (both for DPS and POR). This is consistent with the assumptions $\mathrm{H} 1, \mathrm{H} 2$ and $\mathrm{H} 3$. We also found no significant impact of foreign ownership on the level of dividends paid. The ownership ratio of managers who are considered 
separately is significantly negative and statistically significant at $1 \%$, but when considered together with other ownership ratios, the coefficient impact of managerial ownership becomes statistically insignificant.

Table 4: The level of ownership concentration and enterprise's dividend payout

\begin{tabular}{|c|c|c|c|c|c|c|c|c|c|c|}
\hline & \multicolumn{5}{|c|}{ Dividend per DPS share } & \multicolumn{5}{|c|}{ Dividend payout ratio POR } \\
\hline & (1) & (2) & (3) & (4) & (5) & (6) & $(7)$ & (8) & (9) & $(10)$ \\
\hline Constant & $\begin{array}{c}-2684.1955^{\star * *} \\
(-3.26)\end{array}$ & $\begin{array}{c}-2788.4300^{* \star *} \\
(-3.29)\end{array}$ & $\begin{array}{c}-2756.6227^{* \star \star} \\
(-3.23)\end{array}$ & $\begin{array}{c}-2811.8536^{* \star \star} \\
(-3.22)\end{array}$ & $\begin{array}{c}-2849.7166^{* * *} \\
(-3.35)\end{array}$ & $\begin{array}{c}-0.0254 \\
(-0.16)\end{array}$ & $\begin{array}{c}-0.0448 \\
(-0.27)\end{array}$ & $\begin{array}{c}-0.0547 \\
(-0.33)\end{array}$ & $\begin{array}{c}-1359 \\
(-0.76)\end{array}$ & $\begin{array}{c}-0.0626 \\
(-0.37)\end{array}$ \\
\hline LARGEST & $\begin{array}{c}529.1581^{* * *} \\
(3.65)\end{array}$ & & & & & $\begin{array}{c}0.1367^{\star * *} \\
(4.94)\end{array}$ & & & & \\
\hline $\begin{array}{l}\text { HINDEX } \\
\text { ALL }\end{array}$ & & $\begin{array}{c}237.4754 \\
(1.61)\end{array}$ & & & & & $\begin{array}{c}0.1155^{\star \star *} \\
(3.57)\end{array}$ & & & \\
\hline $\begin{array}{l}\text { HINDEX } \\
\text { _LARGE }\end{array}$ & & & $\begin{array}{c}294.5346^{*} \\
(1.82)\end{array}$ & & & & & $\begin{array}{c}0.1296^{\star \star \star} \\
(3.59)\end{array}$ & & \\
\hline $\begin{array}{l}\text { HINDEX } \\
\text { INSTI }\end{array}$ & & & & $\begin{array}{c}-13.1584 \\
(-0.11)\end{array}$ & & & & & $\begin{array}{l}0.0376 \\
(1.46)\end{array}$ & \\
\hline $\begin{array}{l}\text { HINDEX } \\
\text { FOREIGN }\end{array}$ & & & & & $\begin{array}{c}-105.9215 \\
(-1.09)\end{array}$ & & & & & $\begin{array}{c}-0.0214 \\
(-1.07)\end{array}$ \\
\hline SIZE & $\begin{array}{c}30.1060 \\
(1.04)\end{array}$ & $\begin{array}{c}40.2519 \\
(1.35)\end{array}$ & $\begin{array}{c}37.5832 \\
(1.25)\end{array}$ & $\begin{array}{c}44.0198 \\
(1.46)\end{array}$ & $\begin{array}{c}46.8848 \\
(1.56)\end{array}$ & $\begin{array}{c}-0.0043 \\
(-0.76)\end{array}$ & $\begin{array}{c}-0.0028 \\
(-0.48)\end{array}$ & $\begin{array}{c}-0.0030 \\
(-0.51)\end{array}$ & $\begin{array}{l}0.0011 \\
(0.17)\end{array}$ & $\begin{array}{l}-0.0005 \\
(-0.08)\end{array}$ \\
\hline TANGIBILITY & $\begin{array}{c}-457.6692^{* *} \\
(-2.47)\end{array}$ & $\begin{array}{c}-499.7767^{* \star *} \\
(-2.71)\end{array}$ & $\begin{array}{c}-516.2725^{\star * *} \\
(-2.78)\end{array}$ & $\begin{array}{c}-457.1896^{* *} \\
(-2.46)\end{array}$ & $\begin{array}{c}-459.4994^{* *} \\
(-2.46)\end{array}$ & $\begin{array}{l}0.0050 \\
(0.13)\end{array}$ & $\begin{array}{c}-0.0052 \\
(-0.13)\end{array}$ & $\begin{array}{c}-0.0075 \\
(-0.19)\end{array}$ & $\begin{array}{l}0.0078 \\
(0.19)\end{array}$ & $\begin{array}{l}0.0132 \\
(0.32)\end{array}$ \\
\hline CF_RATIO & $\begin{array}{c}3143.3323^{* \star *} \\
(4.69)\end{array}$ & $\begin{array}{c}2997.8786^{\star \star \star} \\
(4.40)\end{array}$ & $\begin{array}{c}3003.9199^{\star \star \star} \\
(4.41)\end{array}$ & $\begin{array}{c}2992.6323^{\star * *} \\
(4.41)\end{array}$ & $\begin{array}{c}2978.2752^{\star \star \star} \\
(4.35)\end{array}$ & $\begin{array}{l}0.0353 \\
(0.47)\end{array}$ & $\begin{array}{l}0.0268 \\
(0.35)\end{array}$ & $\begin{array}{l}0.0267 \\
(0.35)\end{array}$ & $\begin{array}{l}0.0390 \\
(0.49)\end{array}$ & $\begin{array}{l}0.0271 \\
(0.35)\end{array}$ \\
\hline LIQUIDITY & $\begin{array}{c}1855.7597^{* \star *} \\
(5.46)\end{array}$ & $\begin{array}{c}1885.6862^{* \star *} \\
(5.36)\end{array}$ & $\begin{array}{c}1850.0699^{\star \star \star} \\
(5.21)\end{array}$ & $\begin{array}{c}1908.8635^{\star \star \star *} \\
(5.40)\end{array}$ & $\begin{array}{c}1906.0336^{* \star *} \\
(5.41)\end{array}$ & $\begin{array}{l}0.2666^{\star \star *} \\
(5.22)\end{array}$ & $\begin{array}{c}0.2755^{\star \star *} \\
(5.33)\end{array}$ & $\begin{array}{c}* 0.2707^{\star \star \star} \\
(5.20)\end{array}$ & $\begin{array}{c}0.2905^{\star \star \star *} \\
(5.59)\end{array}$ & $\begin{array}{l}0.2854^{\star \star \star} \\
(5.43)\end{array}$ \\
\hline AGE_INC & $\begin{array}{c}41.6813^{\star * \star *} \\
(3.98)\end{array}$ & $\begin{array}{c}40.2384^{\star \star \star} \\
(3.84)\end{array}$ & $\begin{array}{c}40.1575^{\star \star \star} \\
(3.81)\end{array}$ & $\begin{array}{c}38.1592^{* * *} \\
(3.67)\end{array}$ & $\begin{array}{c}38.1767^{\star * *} \\
(3.69)\end{array}$ & $\begin{array}{c}0.0043^{* *} \\
(2.36)\end{array}$ & $\begin{array}{c}0.0045^{* *} \\
(2.38)\end{array}$ & $\begin{array}{c}0.0043^{* *} \\
(2.27)\end{array}$ & $\begin{array}{c}0.0039^{* *} \\
(2.09)\end{array}$ & $\begin{array}{c}0.0035^{*} \\
(1.88)\end{array}$ \\
\hline ROE & $\begin{array}{c}4355.1427^{\star \star *} \\
(8.40)\end{array}$ & $\begin{array}{c}4513.9410^{* \star *} \\
(8.64)\end{array}$ & $\begin{array}{c}4522.4306^{\star \star \star \star} \\
(8.65)\end{array}$ & $\begin{array}{c}4533.1451^{\text {*** }} \\
(8.63)\end{array}$ & $\begin{array}{c}4610.5529^{* * *} \\
(8.67)\end{array}$ & $\begin{array}{l}-0.0217 \\
(-0.28)\end{array}$ & $\begin{array}{l}-0.0198 \\
(-0.25)\end{array}$ & $\begin{array}{l}-0.0161 \\
(-0.20)\end{array}$ & $\begin{array}{l}-0.0161 \\
(-0.20)\end{array}$ & $\begin{array}{l}-0.0012 \\
(-0.02)\end{array}$ \\
\hline MB & $\begin{array}{c}218.7517^{* * *} \\
(2.92)\end{array}$ & $\begin{array}{c}222.0038^{\star \star \star} \\
(2.89)\end{array}$ & $\begin{array}{c}220.3979^{* \star *} \\
(2.87)\end{array}$ & $\begin{array}{c}214.8432^{\star \star *} \\
(2.77)\end{array}$ & $\begin{array}{c}207.8231^{\text {*** }} \\
(2.70)\end{array}$ & $\begin{array}{c}0.0277^{* *} \\
(2.43)\end{array}$ & $\begin{array}{c}0.0316^{\star * *} \\
(2.72)\end{array}$ & $\begin{array}{c}{ }^{*} 0.0310^{\star \star * *} \\
(2.67)\end{array}$ & $\begin{array}{c}0.0294^{\star *} \\
(2.50)\end{array}$ & $\begin{array}{c}0.0271^{* *} \\
(2.33)\end{array}$ \\
\hline $\begin{array}{l}\text { Control fo } \\
\text { Industry fix }\end{array}$ & & & & & & & & & & \\
\hline Industry fixed ef & Yes & Yes & Yes & Yes & Yes & Yes & Yes & Yes & Yes & Yes \\
\hline Year fixed effect & Yes & Yes & Yes & Yes & Yes & Yes & Yes & Yes & Yes & Yes \\
\hline Number of observations & 3582 & 3514 & 3508 & 3506 & 3501 & 3197 & 3137 & 3131 & 3130 & 3129 \\
\hline Pseudo $\mathrm{R}^{2}$ & 0.0316 & 0.0312 & 0.0311 & 0.0310 & 0.0311 & 0.1121 & 0.1104 & 0.1102 & 0.1009 & 0.0982 \\
\hline
\end{tabular}

Table 5. Types of ownership structure and level of dividend payout

\begin{tabular}{|c|c|c|c|c|c|c|c|c|c|c|}
\hline & \multicolumn{5}{|c|}{ Dividend per DPS share } & \multicolumn{5}{|c|}{ Dividend payout ratio POR } \\
\hline & (1) & (2) & (3) & (4) & (5) & (6) & (7) & (8) & (9) & (10) \\
\hline Constant & $\begin{array}{c}-2481.2749^{\star \star \star} \\
(-3.02)\end{array}$ & $\begin{array}{c}-2302.9930^{* * *} \\
(-2.84)\end{array}$ & $\begin{array}{c}-2831.6548^{* * *} \\
(-3.42)\end{array}$ & $\begin{array}{c}-2637.7896^{* \star *} \\
(-3.20)\end{array}$ & $\begin{array}{c}-2284.6358^{* \star \star} \\
(-2.79)\end{array}$ & $\begin{array}{c}0.0244 \\
(0.16)\end{array}$ & $\begin{array}{l}0.0635 \\
(0.41)\end{array}$ & $\begin{array}{c}-0.0591 \\
(-0.36)\end{array}$ & $\begin{array}{c}-0.0029 \\
(-0.02)\end{array}$ & $\begin{array}{l}0.0751 \\
(0.48)\end{array}$ \\
\hline STATE & $\begin{array}{c}781.8406^{* \star *} \\
(5.64)\end{array}$ & & & & $\begin{array}{c}410.7938^{* *} \\
(2.24)\end{array}$ & $\begin{array}{c}0.1846^{\star * *} \\
(6.54)\end{array}$ & & & & $\begin{array}{c}0.1027^{\star * \star} \\
(2.91)\end{array}$ \\
\hline INSTITUTION & & $\begin{array}{c}831.0404^{\star * *} \\
(5.93)\end{array}$ & & & $\begin{array}{c}595.3271^{* \star *} \\
(3.11)\end{array}$ & & $\begin{array}{c}0.1905^{\star \star *} \\
(7.14)\end{array}$ & & & $\begin{array}{c}0.1274^{\star \star \star} \\
(3.65)\end{array}$ \\
\hline FOREIGN & & & $\begin{array}{c}-243.6403 \\
(-0.84)\end{array}$ & & $\begin{array}{c}-169.1163 \\
(-0.57)\end{array}$ & & & $\begin{array}{l}-0.0605 \\
(-1.05)\end{array}$ & & $\begin{array}{l}-0.0458 \\
(-0.78)\end{array}$ \\
\hline MANAGER & & & & $\begin{array}{c}-782.4452^{* * *} \\
(-2.72)\end{array}$ & $\begin{array}{c}-33.7488 \\
(-0.11)\end{array}$ & & & & $\begin{array}{c}-0.2087^{\star \star *} \\
(-3.16)\end{array}$ & $\begin{array}{l}-0.0393 \\
(-0.58)\end{array}$ \\
\hline SIZE & $\begin{array}{c}26.1936 \\
(0.90)\end{array}$ & $\begin{array}{c}16.2308 \\
(0.56)\end{array}$ & $\begin{array}{c}43.2001 \\
(1.48)\end{array}$ & $\begin{array}{c}37.5540 \\
(1.28)\end{array}$ & $\begin{array}{c}15.8396 \\
(0.55)\end{array}$ & $\begin{array}{c}-0.0051 \\
(-0.90)\end{array}$ & $\begin{array}{c}-0.0073 \\
(-1.32)\end{array}$ & $\begin{array}{c}-0.0011 \\
(-0.19)\end{array}$ & $\begin{array}{r}-0.0028 \\
(-0.48)\end{array}$ & $\begin{array}{l}-0.0076 \\
(-1.36)\end{array}$ \\
\hline TANGIBILITY & $\begin{array}{c}-551.6442^{\star \star *} \\
(-3.02)\end{array}$ & $\begin{array}{c}-505.9541^{* \star *} \\
(-2.72)\end{array}$ & $\begin{array}{c}-417.0420^{\text {** }} \\
(-2.26)\end{array}$ & $\begin{array}{c}-428.3684^{\star *} \\
(-2.33)\end{array}$ & $\begin{array}{c}-552.0187^{* \star \star} \\
(-3.01)\end{array}$ & $\begin{array}{l}-0.0145 \\
(-0.37)\end{array}$ & $\begin{array}{r}-0.0024 \\
(-0.06)\end{array}$ & $\begin{array}{l}0.0137 \\
(0.34)\end{array}$ & $\begin{array}{l}0.0109 \\
(0.28)\end{array}$ & $\begin{array}{l}-0.0125 \\
(-0.33)\end{array}$ \\
\hline CF_RATIO & $\begin{array}{l}3100.2921^{* * *} \\
(4.63)\end{array}$ & $\begin{array}{c}3040.6689^{\star * *} \\
(4.58)\end{array}$ & $\begin{array}{c}3221.4174^{\star \star \star} \\
(4.80)\end{array}$ & $\begin{array}{c}3189.8019^{* * *} \\
(4.76)\end{array}$ & $\begin{array}{c}3030.7445^{* * *} \\
(4.55)\end{array}$ & $\begin{array}{l}0.0259 \\
(0.35)\end{array}$ & $\begin{array}{l}0.0108 \\
(0.14)\end{array}$ & $\begin{array}{l}0.0559 \\
(0.75)\end{array}$ & $\begin{array}{l}0.0438 \\
(0.59)\end{array}$ & $\begin{array}{l}0.0073 \\
(0.10)\end{array}$ \\
\hline LIQUIDITY & $\begin{array}{c}1786.4154^{* * *} \\
(5.35)\end{array}$ & $\begin{array}{c}1708.0510^{\star \star \star \star ~} \\
(5.04)\end{array}$ & $\begin{array}{c}1891.3483^{* \star *} \\
(5.57)\end{array}$ & $\begin{array}{c}1812.4395^{\star \star \star} \\
(5.33)\end{array}$ & $\begin{array}{c}1705.4105^{\star \star \star} \\
(5.07)\end{array}$ & $\begin{array}{c}0.2526^{* \star *} \\
(5.12)\end{array}$ & $\begin{array}{l}0.2354^{* \star *} \\
(4.67)\end{array}$ & $\begin{array}{l}0.2757^{\star \star \star *} \\
(5.39)\end{array}$ & $\begin{array}{c}0.2552^{\star \star \star *} \\
(5.00)\end{array}$ & $\begin{array}{c}0.2333^{\star * \star} \\
(4.72)\end{array}$ \\
\hline AGE_INC & $\begin{array}{c}41.0249^{\star \star *} \\
(3.90)\end{array}$ & $\begin{array}{c}42.9492^{\star \star \star} \\
(4.08)\end{array}$ & $\begin{array}{c}39.9472^{\star * *} \\
(3.84)\end{array}$ & $\begin{array}{c}41.2855^{\star \star \star} \\
(3.96)\end{array}$ & $\begin{array}{c}42.7481^{* * \star} \\
(4.03)\end{array}$ & $\begin{array}{c}0.0041^{* *} \\
(2.17)\end{array}$ & $\begin{array}{c}0.0045^{\star *} \\
(2.44)\end{array}$ & $\begin{array}{l}0.0039^{* *} \\
(2.11)\end{array}$ & $\begin{array}{l}0.0042^{* \star} \\
(2.27)\end{array}$ & $\begin{array}{c}0.0044^{* *} \\
(2.39)\end{array}$ \\
\hline ROE & $\begin{array}{c}4280.2858^{* * *} \\
(8.38)\end{array}$ & $\begin{array}{c}4317.5481^{\text {*** }} \\
(8.32)\end{array}$ & $\begin{array}{c}4346.5726^{\star \star *} \\
(8.41)\end{array}$ & $\begin{array}{l}4366.1131^{\star \star *} \\
(8.42)\end{array}$ & $\begin{array}{c}4284.7004^{\star \star \star} \\
(8.32)\end{array}$ & $\begin{array}{c}-0.0486 \\
(-0.64)\end{array}$ & $\begin{array}{c}-0.0306 \\
(-0.39)\end{array}$ & $\begin{array}{r}-0.0300 \\
(-0.38)\end{array}$ & $\begin{array}{l}-0.0202 \\
(-0.26)\end{array}$ & $\begin{array}{l}-0.0417 \\
(-0.54)\end{array}$ \\
\hline MB & $\begin{array}{c}242.1730^{* * *} \\
(3.30)\end{array}$ & $\begin{array}{c}227.3692^{\star \star *} \\
(3.01)\end{array}$ & $\begin{array}{c}225.6771^{\star \star *} \\
(3.03)\end{array}$ & $\begin{array}{c}228.7786^{\star * *} \\
(3.04)\end{array}$ & $\begin{array}{c}234.2524^{\star \star *} \\
(3.13)\end{array}$ & $\begin{array}{c}0.0340^{\star * \star} \\
(3.10)\end{array}$ & $\begin{array}{c}0.0303^{\star \star \star} \\
(2.61)\end{array}$ & $\begin{array}{c}0.0299^{* \star *} \\
(2.65)\end{array}$ & $\begin{array}{c}0.0306^{\star \star \star} \\
(2.65)\end{array}$ & $\begin{array}{c}0.0324^{\star \star \star} \\
(2.88)\end{array}$ \\
\hline Control for & & & & & & & & & & \\
\hline Industry & Yes & Yes & Yes & Yes & Yes & Yes & Yes & Yes & Yes & Yes \\
\hline Year fixe & Yes & Yes & Yes & Yes & Yes & Yes & Yes & Yes & Yes & Yes \\
\hline Numbe & 3582 & 3583 & 3583 & 3582 & 3582 & 3197 & 3197 & 3197 & 3197 & 3197 \\
\hline Pseudo $\mathrm{R}^{2}$ & 0.0323 & 0.0325 & 0.0312 & 0.0314 & 0.0327 & 0.1279 & 0.1322 & 0.0983 & 0.1048 & 0.1395 \\
\hline
\end{tabular}




\subsection{Subsample testing of the relationship between Ownership structure and profit distribution on} HOSE and HNX

We reconsiders regressions about the distribution of listed companies' profits in two ways: the affordability of dividend payout and the level of dividend payout. For the affordability of dividend payout, the two models used are LPM and Logistic to determine the probability of dividend payout of listed companies in each sub-sample. With level of dividend payout, we still implements the Tobit regression for the two dependent variables: dividend payout ratio (POR) and dividends per share (DPS). The regression results are reported in Table 6.

The decision to distribute profits of listed companies on the HNX tends to be more affected by the ownership structure, especially the probability of enterprises paying dividends in the year. In HNX enterprises, the degree of ownership structure (except for the degree of ownership concentration of foreign investors) has a positive and statistically significant coefficient (at least $5 \%$ ). Meanwhile, the degree of ownership concentration of listed companies on HOSE is only positively and positively correlated with the probability of paying dividends in the proportion of ownership of the largest investors. In listed companies on HOSE and HNX, the proportion of state ownership and institutional investors has a positive impact on the company's dividend payment decision. However, for companies listed on the HOSE, the ownership ratio of managers is inversely proportional to the ability to pay dividends. The result of dividend payout through DPS and POR is similar to the dividend payout ratio of the business.

Table 6. Ownership Structure and Dividend Payout Decision on HOSE and HNX

\begin{tabular}{|c|c|c|c|c|}
\hline \multirow{3}{*}{$\begin{array}{l}\text { Dependent variables: PAYOUT } \\
\text { Models }\end{array}$} & \multicolumn{4}{|c|}{ Part A: The probability of dividend payout of the business } \\
\hline & \multicolumn{2}{|c|}{ HOSE } & \multicolumn{2}{|c|}{$H N X$} \\
\hline & $L P M$ & Logistic & $L P M$ & Logistic \\
\hline LARGEST & $\begin{array}{l}0.1592^{* \star *} \\
(2.65)\end{array}$ & $\begin{array}{c}0.8255^{\star *} \\
(2.30)\end{array}$ & $\begin{array}{c}0.2377^{\star \star \star} \\
(4.04)\end{array}$ & $\begin{array}{c}1.2834^{* * *} \\
(3.96)\end{array}$ \\
\hline HINDEX_ALL & $\begin{array}{c}0.0600 \\
(0.77)\end{array}$ & $\begin{array}{c}0.4439 \\
(0.95)\end{array}$ & $\begin{array}{c}0.2093^{* * *} \\
(3.21)\end{array}$ & $\begin{array}{c}1.1519^{* * *} \\
(3.10)\end{array}$ \\
\hline HINDEX_LARGE & $\begin{array}{c}0.0608 \\
(0.72)\end{array}$ & $\begin{array}{c}0.4740 \\
(0.96)\end{array}$ & $\begin{array}{c}0.2562^{* * *} \\
(3.47)\end{array}$ & $\begin{array}{c}1.4270^{* * *} \\
(3.36)\end{array}$ \\
\hline HINDEX_INSTI & $\begin{array}{c}-0.0773 \\
(-1.39)\end{array}$ & $\begin{array}{c}-0.3238 \\
(-1.03)\end{array}$ & $\begin{array}{c}0.1179^{* *} \\
(2.45)\end{array}$ & $\begin{array}{c}0.6367^{* *} \\
(2.53)\end{array}$ \\
\hline HINDEX_FOREIGN & $\begin{array}{c}-0.0039 \\
(-0.09)\end{array}$ & $\begin{array}{c}-0.0203 \\
(-0.08)\end{array}$ & $\begin{array}{c}-0.0182 \\
(-0.42)\end{array}$ & $\begin{array}{c}-0.0946 \\
(-0.40)\end{array}$ \\
\hline STATE & $\begin{array}{c}0.2966^{* * *} \\
(4.58)\end{array}$ & $\begin{array}{c}1.7579^{* * *} \\
(4.48)\end{array}$ & $\begin{array}{c}0.3320^{* * *} \\
(5.78)\end{array}$ & $\begin{array}{c}1.9702^{* * *} \\
(5.73)\end{array}$ \\
\hline INSTITUTION & $\begin{array}{c}0.2593^{* * *} \\
(4.40)\end{array}$ & $\begin{array}{c}1.4138^{* * *} \\
(3.94)\end{array}$ & $\begin{array}{c}0.3256^{* * *} \\
(5.89)\end{array}$ & $\begin{array}{c}1.8235^{\star * * *} \\
(5.86)\end{array}$ \\
\hline FOREIGN & $\begin{array}{c}-0.0906 \\
(-0.68)\end{array}$ & $\begin{array}{c}-0.4931 \\
(-0.62)\end{array}$ & $\begin{array}{c}-0.0637 \\
(-0.51)\end{array}$ & $\begin{array}{c}-0.4871 \\
(-0.60)\end{array}$ \\
\hline MANAGER & $\begin{array}{c}-0.2457^{\star *} \\
(-2.27)\end{array}$ & $\begin{array}{c}-1.2153^{* *} \\
(-2.09)\end{array}$ & $\begin{array}{c}-0.1011 \\
(-0.66) \\
\end{array}$ & $\begin{array}{c}-0.5153 \\
(-0.69)\end{array}$ \\
\hline \multicolumn{5}{|c|}{ Part B: level of dividend payout (Tobit) } \\
\hline & DPS & POR & DPS & POR \\
\hline LARGEST & $\begin{array}{c}641.7582^{\star * *} \\
(2.98)\end{array}$ & $\begin{array}{c}0.1288^{* * *} \\
(3.01)\end{array}$ & $\begin{array}{c}483.4834^{* *} \\
(2.48)\end{array}$ & $\begin{array}{c}0.1453^{* * *} \\
(4.04)\end{array}$ \\
\hline HINDEX_ALL & $\begin{array}{c}152.7144 \\
(0.64)\end{array}$ & $\begin{array}{c}0.0896^{*} \\
(1.71)\end{array}$ & $\begin{array}{c}318.1484^{*} \\
(1.71)\end{array}$ & $\begin{array}{c}0.1181^{* * *} \\
(2.80)\end{array}$ \\
\hline HINDEX_LARGE & $\begin{array}{c}146.6467 \\
(0.56)\end{array}$ & $\begin{array}{c}0.0863 \\
(1.54)\end{array}$ & $\begin{array}{c}442.3696^{* *} \\
(2.17)\end{array}$ & $\begin{array}{c}0.1493^{* * *} \\
(3.05)\end{array}$ \\
\hline HINDEX_INSTI & $\begin{array}{c}-224.6784 \\
(-1.25)\end{array}$ & $\begin{array}{c}-0.0001 \\
(-0.00)\end{array}$ & $\begin{array}{c}99.8418 \\
(0.66)\end{array}$ & $\begin{array}{c}0.0508 \\
(1.52)\end{array}$ \\
\hline HINDEX_FOREIGN & $\begin{array}{c}-97.0865 \\
(-0.61)\end{array}$ & $\begin{array}{c}-0.0059 \\
(-0.20)\end{array}$ & $\begin{array}{c}-132.3660 \\
(-1.07)\end{array}$ & $\begin{array}{c}-0.0326 \\
(-1.17)\end{array}$ \\
\hline STATE & $\begin{array}{c}994.8795^{\star * *} \\
(4.56)\end{array}$ & $\begin{array}{c}0.2245^{* * *} \\
(4.86)\end{array}$ & $\begin{array}{c}724.3548^{* * *} \\
(3.97)\end{array}$ & $\begin{array}{c}0.1518^{* * *} \\
(4.04)\end{array}$ \\
\hline INSTITUTION & $\begin{array}{c}1024.9585^{* * *} \\
(4.64)\end{array}$ & $\begin{array}{l}0.1981^{* * *} \\
(4.69)\end{array}$ & $\begin{array}{c}719.5136^{* * *} \\
(4.09)\end{array}$ & $\begin{array}{c}0.1863^{* * *} \\
(5.25)\end{array}$ \\
\hline FOREIGN & $\begin{array}{c}-253.5465 \\
(-0.63)\end{array}$ & $\begin{array}{c}-0.1064 \\
(-1.39)\end{array}$ & $\begin{array}{c}-373.5734 \\
(-1.04)\end{array}$ & $\begin{array}{c}-0.0270 \\
(-0.30)\end{array}$ \\
\hline MANAGER & $\begin{array}{c}-1317.6005^{\star * *} \\
(-3.29)\end{array}$ & $\begin{array}{c}-0.2372^{\star * *} \\
(-2.84) \\
\end{array}$ & $\begin{array}{c}61.7312 \\
(0.14) \\
\end{array}$ & $\begin{array}{c}-0.1268 \\
(-1.15) \\
\end{array}$ \\
\hline
\end{tabular}




\subsection{Robustness tests}

In this part, some tests are conducted to check the model quality to ensure the results were meaningful. In addition, robustness tests are also aimed at identifying defects of the model, dealing with some possible endogeneity problems.

We retakes some basic regression models (focusing on GMM, LPM, Logit, Tobit) using dummy variables in the ownership structure of the business. Here, we establishes dummy variables that receive value 1 if the level of ownership concentration (the ownership proportion of largest investors and $\mathrm{H}$-index of all major investors) and Ownership type (state ownership, institutional investors, foreign investors and managers) of the firm is high and it gets value 0 if low. High level is defined as the level of ownership that is higher than the average of the overall sample (except $\mathrm{H}$ index, $\mathrm{H}$-index> 0.5). When using dummy variables as independent variables in the model, the significance of the regression coefficients becomes the mean value comparison of financial decisions, performance and corporate value among listed companies. They have a high ownership structure as well as level of concentration and a high ownership proportion of ownership compared to companies with a dispersed ownership structure and a low ownership ratio.

The regression results of the dummy variables are similar to the regression results found in the main study. Listed firms have a high degree of ownership concentration, the proportion of state ownership and ownership of institutional investors tend to pay more dividends than firms with dispersed ownership. State ownership and institutional investors are low. At the same time, firms with high ownership of managers tend to pay less dividends, but higher returns on equity.

Issues such as heteroscedasticity or autocorrelation may be present in the regression and because collected data is panel data that has been resolved by the research team through using of White's robust heteroscedasticity-robust (1980) robustness and Petersen's sample-clustering robust (2009) to calculate the t-statistics and z-statistics values for testing the statistical significance of the results.

One problem that can distort regression results is that of multipliers. These are two or more explanatory variables that are highly correlated with each other, or in other words, this independent variable can explain Linear for other independent variables. To look at this issue, it may be based on two directions. Firstly, according to the Pearson correlation matrix, it can be seen that the correlation coefficients between the explanatory variables used in the model are not too high except for some variables with similarly set up methods such as MB coefficient And Tobin's $Q$, the overall $\mathrm{H}$-index and the largest investor's $\mathrm{H}$-index. During the study, the team did not put these highly correlated variables into the same regression model. Secondly, during the regression implementation, the team conducted a variance inflation factor (VIF) test for multicollinearity detection in the model. VIF is a test that is commonly used in research. With a regression model with $\mathrm{k}$ explanatory variables, the VIF of each variable is calculated as follows:

$$
V I F_{k}=\frac{1}{1-R_{k}^{2}}
$$

Where, $\mathrm{R} 2 \mathrm{k}$ is the $\mathrm{R} 2$ value obtained from the independent variable regression $\mathrm{k}$ under the remaining independent variables. The VIF of the $\mathrm{k}$ variable is greater than 10 indicates that the explanatory variable $\mathrm{k}$ has a very serious collinearity and needs to be processed immediately. The VIF test results show that there are no multiple collinearities in the regression models of the study group (the VIF coefficients are small and have no coefficients that are greater than 10).

\section{Conclusions}

This paper focuses on the relationship between ownership structure and dividend policy of the firms in the Vietnamese market in the period from 2009 to 2015. We examine (1) the impact of ownership structure on the probability of dividend payment, and (2) whether ownership structure affects the decision of firms on the amount of dividend payment.

The LPM regressions and the Logit regressions are used to test the impact of ownership structure on the probability of dividend payment. The Tobit regressions are used to test the impact of ownership structure on the amount of dividend payment. Firm's characteristics are used as 
control variables. Industry dummies and year dummies are used to capture the unobserved industry-specific and time-varies variables that could potentially affect the results in this paper.

We found evidences that the level of concentration of ownership structure, state ownership and institutional investors' ownership have a positive effect on making decision whether to pay dividends of listed companies on the Vietnamese stock market, especially those listed on the HNX. State ownership and institutional investors' ownership have a positive impact on the level of dividend payout of an enterprise, but the ownership of foreign investors with the level of dividend payout of the business is not available with statistics. This is similar when considering the impact of ownership by the administrator.

Research subjects may face the issue of survivorship bias due to the specific subject of research companies listed on the two stock exchanges of Vietnam, each of which has the listing rules and criteria separately. During the research period 2009-2015, there may be companies that are canceled or bankrupt (listed companies are still in the sample). Survivorship bias occurs when research takes into account only surviving companies in the sample during the study period but ignores the impact of companies that are no longer in the sample for a variety of reasons. To overcome this situation, as far as the data could be collected, the team put the company's delisted and bankruptcy companies in 2009-2015 into the sample. The regression results are similar to those found above. It is, therefore, possible to ensure that the results of the study are not severely affected by the survivorship bias.

Regression results may also be biased and inconsistent, and test value such as t-statistics may deviate if the size of the overall sample is small. The sample of the research team has 4,494 observations over time and according to the company. However, to ensure the research results, the team performs bootstrap analysis. The bootstrap method can help to increase the accuracy of testing through replication (Mackinnon, 2002). Using econometric software, replication was done 1000 times to generate empirical t-statistics and the team was able to use t-statistics to test the statistical significance of the regression coefficients found in the subject. Although it is not reported here, the results from the bootstrap analysis are similar to those of the research team found above.

Our study contributes to the gap of knowledge on the effect of ownership structure on many aspects of firm's financial decisions, especially the distribution policy of firms in East Asia region. The findings may suggest some further studies in related issues. For instance, why ownership concentration shows the change of sign in different periods of time; or why foreign holdings do not have any impact on dividend policy, which is not consistent with both the incentive alignment hypothesis and the entrenchment hypothesis; etc.

\section{References}

Abdullah, N.M., Ahmad., \& Rosland, S. (2012). The influence of ownership structure on the firms (Evidence from Karachi Stock Exchange 100 index). International of Business Management and Economics, 1(1), 58-69.

Aguenaou, S., Farooq, O. and Di, H. (2013). Dividend Policy and Ownership Structure: Evidence from the Casablanca Stock Exchange. GSTF International Journal on Business Review (GBR), 2 (4), 116-121.

Al-Shubiri, F., Al-Taleb, G. \& Al-zoued, A. (2012). The Relationship between Ownership Structure and Dividend Policy: An Empirical Investigation. Review of International Comparative Management 13(4), 644-657.

Chai, D.H. (2010). Foreign corporate ownership and dividends. Working paper No.401, Center for business research, University of Cambridge.

Easterbrook, F. (1984). Two agency cost explainations of dividends. Journal of Political economy, 88(2), 288-307.

El-Masry, AA, Abd-Elsalam, O \& Elsegini, S (2008). Board composition, ownership structure and dividend policies in an emerging market: Further evidence from CASE 50", Managerial Finance, vol. 34, no. 12, pp. 953 - 964.

Elston, J.A., Hofler, R., \& Lee (2011). Dividend policy anf Institutional ownership: Empirical evidence using propensity score matching estimator. Journal of Accounting \& Finance, 11(1), 89-102

Hai Ly, T.Thi (2015). Ownership structure and dividen policy of listed companies: evidences from Vietnam. Journal of Development and Intergration in Vietnam, 23, 72-78

Harada, K, \& Nguyen, P. (2011). Ownership concentration and dividend policy in Japan. Managerial Finance Review, 76(2), 323-379

Holderness, C.G. and D.P. Sheehan, (1988). The role of majority shareholders in publicly held corporations, Journal of Financial Economics, 20, 317-346.

Islam Azzam (2010). The Impact of Institutional Ownership and Dividend Policy on Stock Returns and Volatility: Evidence from Egypt", International Journal of Business, Volume 15 (4), pp 443-458. 
Jayesh Kumar (2004). Does ownership structure influence firm value? Evidence from India, The journal of Entrepreneurial Finance and Business Ventures, Vol.9, No. 2, October 2004, pp. 61-93

Jensen, M. C. (1986). Agency costs of free cash flow, corporate finance, and takeovers. The American economic review, 76(2), 323-329.

Jensen, M.C \& Meckling, W.H (1976). Theory of the firm: Managerial behaviour, Agency costs and ownership structure. Journal of Financial Economics, 3, 305-360

Kumar, D.S and Wadhwa,R. (2013). Ownership structures and dividend policy: A study of Bombay stock Exchange-500, Global Journal of Management and Business studies, Vol. 3, No. 4, 2013, pp. 434-439

$\mathrm{Li}$, k., \& Zhao, X. (2008). Asymmetric information and dividend policy. Financial management, 37(4), 673-694

Liu, Q., Tian, G. and Wang, X. (2011). The effect of ownership structure on leverage decision: new evidence from Chinese listed firms, Journal of the Asia Pacific economy, Vol. 16, No. 2, pp. 254-276

Mancinelli, L., \& Ozkan, A. (2006). Ownership structure and dividend policy: Evidence from Italian firms. The European Journal of Finance, Volume 12, Number 3, 265-282.

Maury, C. B., and Pajuste, A. (2002). Controlling shareholders, agency problems, and dividend policy in Finland. LTA, 1(2).

Mehar, A. (2005). Corporate Governance and Dividend Policy", Pakistan Economic and Social Review, vol. 1, no. 43, pp. 115-128.

Michael C. Jensen and William H. Meckling. (1976). Theory of the firm: Managerial behavior, Agency costs and ownership structure, Journal of Financial Economics, October, 1976, Vol. 3, No. 4, pp. 305-360.

Michael C. Jensen, (1986). Agency cost of free cash flow, Corporate Finance and Take over, The American Economic Review, Vol. 76, No. 2, Papers proceedings of the ninety eighth Annual meeting of the American Economic Association (May 1986), pp 323-329

Miller, M.H., \& Rock, K. (1985). Dividend policy under asymmertric information. The journal of Finance, 40(4), 1031-1070

Naceur, S, Goaied, M \& Belanes, A (2006). On the Determinants and Dynamics of Dividend Policy.", International Review of Finance, vol. 6, pp. 1-23.

Nasrum, M. (2015). The influence of ownership structure, corporate governance, investment decision, financial decision and dividend policy on the value of firm manufacturing companies listed on the Indonesian Stock Exchange, International journal of Science and Research, Vol. 4, Issue 2, February 2015, pp. 864-866

Nawaiseh, M.A (2013). Dividend policy and ownership structure: an applied study on induatrial companies in Amman stock exchange. Journal of management reseach, 5(2), 83-106.

Pindado, E. (2017). Reseaching the entrepreneurial behaviour of new and existingventures in European agriculture.

Porta, R. L., F. Lopez-De-Silanes, A. Shleifer, and R. W. Vishny [2000], Agency Problems and Dividend Policies around the World, The Journal of Finance.

Rozeff, M.S. (1982). Growth, Beta and Agency costs as determinants of dividend payout ratios. Journal of Financial research, 5(3), 249-259.

Samarakoon, L. (1999). The ownership structure of Srilanka companies. Sri Lanka journal of management, 4 , 143-1711.

Sharif, S. J. S., Salehi, M., andBahadori, H. (2010). Ownership Structure of Iranian Evidence and Payout Ratio. Asian Social Science, 6(7), p36.

Short, H., Zhang, H. and Keasey, K. (2002). The link between dividend policy and institutional ownership. Journal of Corporate Finance, Vol. 8, pp. 105-22.

Stephen A. Ross, (1977). The Determination of Financial Structure: The Incentive-Signalling Approach, The Bell Journal of Economics, Vol. 8, No. 1, 1977, pp.23-40

Sung, W.J and Young, K.K (2007). Ownership structure and share repurchases in an emerging market: incentive alignment or entrenchment?, Working paper, Seoul National University

Thanatawee, Y. (2013). Ownership structure and dividend policy: Evidence from Thailand, International Journal of Economics and Finance, Vol. 5, No. 1, 2013, pp. 121-132

Thanatawee, Y. (2014) Ownership structure and dividend policy: Evidence from China, International Journal of Economics and Finance, Vol. 6, No. 8, 2014, pp. 197-204

Ullah,H., Asma, F. and Khan, F. (2012). The impact of ownership structure on dividend policy: Evidence from Emerging markets KSE-100 Index Pakistan, International Journal of Business and Social Science, Vol. 3, No. 9, May 2012, pp. 298-307

Vinh, D, Q. (2014). TheEffect Of ForeignOwnership On DividendPolicy: The Case Of Listed Companies On Hose. Master of Business Administration,Vietnam National Universıty - HoChiMinh City International University, School Of Business, Vietnam.

Warrad, L. (2012). The effect of ownership structure on dividend payout policy: Evidence from Jordanian context, International journal of economics and finance, 4(2), 187-195.

Wiberg, D., (2008). Institutional Ownership - The Anonymous Capital, JIBS Dissertation Series, No. 48. 